\title{
Fusing East and West Leads a Way to Global Competitiveness in Emerging Economy: Source of China's Conspicuous Strength in Solar Industry
}

\author{
Narasimalu Srikanth \\ National University of Singapore, Singapore \\ Chihiro Watanabe \\ Tokyo Seitoku University, Japan
}

\begin{abstract}
In light of a conspicuous strength in China's solar industry in recent years this paper analyzes an institutional source of its strength. Empirical analysis was conducted focusing on the interaction between indigenous semiconductor industry ("East") and newly emerging solar industry in absorption of global best practices ("West") thereby fusion between them was demonstrated. Success of this fusion can be attributed to a joint work between industry's intensive effort in learning global best practices for exploring new business and government's catalytic role for the attainment of decarbonisation society for nation's sustainability. This suggests a new insight for growing economy for its development of global competitive industry.
\end{abstract}

Keywords: Fusion, learning, global best practices, growing economy, global competitiveness

\section{INTRODUCTION}

\section{China's Conspicuous Strength in Solar Industry}

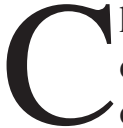

hina has demonstrated in the recent years as the world's largest solar cell producer as shown in Fig. 1. In 2001 China produced world's solar cells and today four of the top 5 solar cell producers are from China and 3 of the five module producers are.Significant growth in the Chinese solar energy Industry has caused the prices of solar panels to drop worldwide ${ }^{1}$. Chinese manufacturers' lower prices are being interpreted and complainedto the extent of dumpinginto USA ${ }^{2}$ (Melanie Hart (2011)) and in Europe ${ }^{3}$ (Reuters (2012)). It is also interesting to note that China with rich solar energy ${ }^{4}$ of 5000 mega joules per square meter on at least two-third of its region that spread to a vast land of 9.6 million square kilometre but yet represents a meagre internal PV market. Table 1 and 2 lists the annual and cumulative installations of solar PV installations in different countries which clearly show the West leads significantly than China. The reason being, the highly anticipated national feed in tariff (FIT) was dropped indefinitely until2011 as PV generation cost was deemed too high during 2006.After spiking in 2006, prices of crystalline

Journal of Technology Management for Growing Economies

Vol. 3 No. 2

October 2012 pp. 7-53

\section{ChItKARA 司 UNIVERSITY}

C 2012 by Chitkara University. All Rights Reserved. 
Srikanth, N.

Watanabe, C.

silicon PV cells and modules fell by 70 percent through 2011. Only since 2010 that their installed capacity has seen a recognizable growth moving from off-grid stand alone systems to grid-connected applications such as building integrated PV systems and large scale PV power stations. But what interest the research circleis to understand thateven with poor internal demand, how did China acquire its knowledge to reach the world's largest production capability 5 and thus what other reasons drive such conspicuous growth. The reality has been that China has effectively used its internal know-how with external knowledge to increase production and thus a key role in reducing the cost.

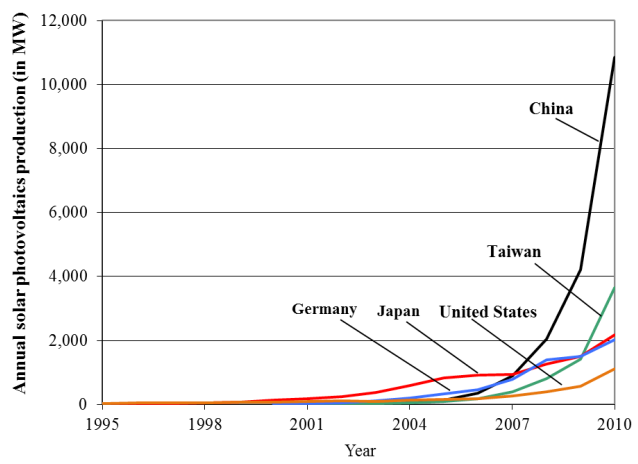

Figure 1: Annual photovoltaic production in different countries (2000 2010).

Source: Earth Policy Institute (2012).

Table 1: Worldwide annual installation of solar PV installations from (2000 - 2010)

\begin{tabular}{|l|c|c|c|c|c|c|c|c|c|c|c|c|}
\hline & $\mathbf{2 0 0 0}$ & $\mathbf{2 0 0 1}$ & $\mathbf{2 0 0 2}$ & $\mathbf{2 0 0 3}$ & $\mathbf{2 0 0 4}$ & $\mathbf{2 0 0 5}$ & $\mathbf{2 0 0 6}$ & $\mathbf{2 0 0 7}$ & $\mathbf{2 0 0 8}$ & $\mathbf{2 0 0 9}$ & $\mathbf{2 0 1 0}$ & $\mathbf{2 0 1 1}$ \\
\hline China & 0 & 11 & 15 & 10 & 9 & 4 & 12 & 20 & 45 & 228 & 520 & 2,200 \\
\hline USA & 23 & 31 & 46 & 65 & 92 & 117 & 149 & 212 & 349 & 539 & 983 & 2,234 \\
\hline EU & 53 & 94 & 142 & 201 & 708 & 1,002 & 987 & 1,972 & 5,297 & 5,803 & 13,397 & 21,939 \\
\hline Apac $^{\mathbf{a}}$ & 114 & 136 & 186 & 225 & 276 & 296 & 322 & 283 & 563 & 766 & 1,618 & 2,653 \\
\hline ROW $^{\mathbf{b}}$ & 88 & 56 & 80 & 77 & 29 & 10 & 105 & 42 & 76 & 80 & 284 & 508 \\
\hline Total & 278 & 328 & 469 & 578 & 1,114 & 1,429 & 1,575 & 2,529 & 6,330 & 7,416 & 16,802 & 29,534 \\
\hline
\end{tabular}

Source: European Photovoltaic Industry Association (2012).

${ }^{a}$ Asean and pacific countries.

${ }^{b}$ Rest of the world.

At world level, Solar cell and Solar Module Industry achieved rapid development in 2010, in terms of Global Capacity production growth rate close to $100 \%$, while the Installation statistics shows that the Global Total Installation is about

Journal of Technology Management for Growing Economies, Volume 3, Number 2, October 2012 
15.6GW, far more than $6.43 \mathrm{GW}$ in 2009 . This was achievable due to China contributing to the Global Solar Module output of 43\% share in 2010.

Table 2 Worldwide cumulative installation of solar PV (2000 - 2010)

\begin{tabular}{|l|c|c|c|c|c|c|c|c|c|c|c|c|}
\hline & $\mathbf{2 0 0 0}$ & $\mathbf{2 0 0 1}$ & $\mathbf{2 0 0 2}$ & $\mathbf{2 0 0 3}$ & $\mathbf{2 0 0 4}$ & $\mathbf{2 0 0 5}$ & $\mathbf{2 0 0 6}$ & $\mathbf{2 0 0 7}$ & $\mathbf{2 0 0 8}$ & $\mathbf{2 0 0 9}$ & $\mathbf{2 0 1 0}$ & $\mathbf{2 0 1 1}$ \\
\hline China & 19 & 30 & 45 & 55 & 64 & 68 & 80 & 100 & 145 & 373 & 893 & 3,003 \\
\hline USA & 146 & 177 & 222 & 287 & 379 & 496 & 645 & 856 & 1,205 & 1,744 & 2,820 & 5,053 \\
\hline EU & 154 & 248 & 389 & 590 & 1,297 & 2,299 & 3,285 & 5,257 & 10,554 & 16,357 & 20,777 & 51,716 \\
\hline Apac $^{\text {a }}$ & 355 & 491 & 677 & 902 & 1,178 & 1,475 & 1,797 & 2,080 & 2,643 & 3,409 & 5,116 & 7,760 \\
\hline ROW $^{\mathbf{b}}$ & 751 & 807 & 887 & 964 & 993 & 1,003 & 1,108 & 1,150 & 1,226 & 1,306 & 1,200 & 1,717 \\
\hline Total & 1,425 & 1,753 & 2,220 & 2,798 & 3,911 & 5,341 & 6,915 & 9,443 & 15,773 & 23,189 & 30,806 & 69,249 \\
\hline
\end{tabular}

Source: European Photovoltaic Industry Association (2012).

${ }^{a}$ Asean and pacific countries.

${ }^{b}$ Rest of the world.

\section{Solar cell technologies and value chain}

Photovoltaic technology helps convert the solar energy into electrical energy (Chetan (2009)), and China is dominant with the first generation crystalline silicon (C-Si)technology followed by the second popular thin film solar cell (TF-Si) technology which countries such as USA is dominant in terms of costcompetitiveness(Yang $\mathrm{Mu}$ et al.(2010)).Fig. 2 describes the various steps of the production chain in China.

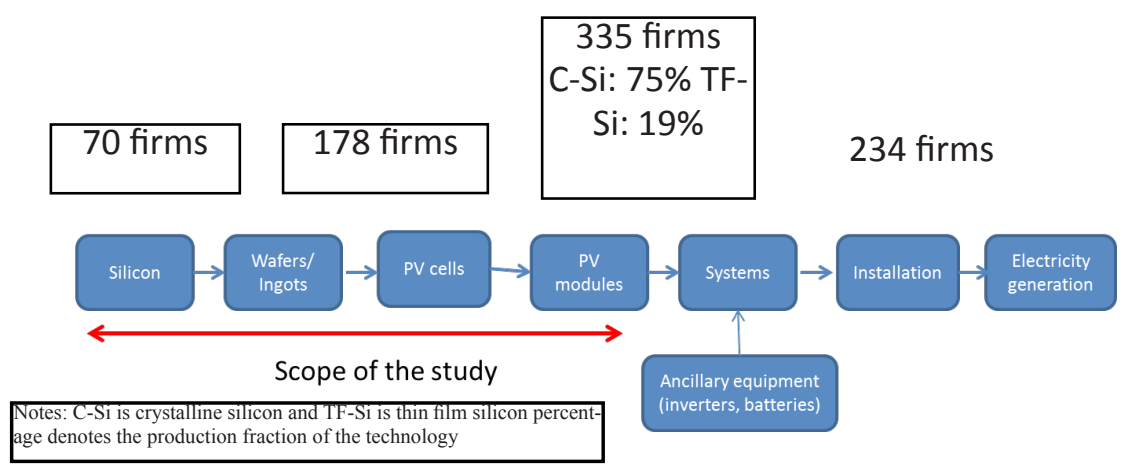

Figure 2.Solar PV production chain with indicative number of firms in China (2011).

The solar cell indicated in dotted line in Fig. 2, has few important steps in the manufacturing process that can be depicted as shown in below figure and is mostly similar to the semiconductor manufacturing process which is illustrated in Fig. 3 (Chetan, 2009). 
Srikanth, N.

Watanabe, C.

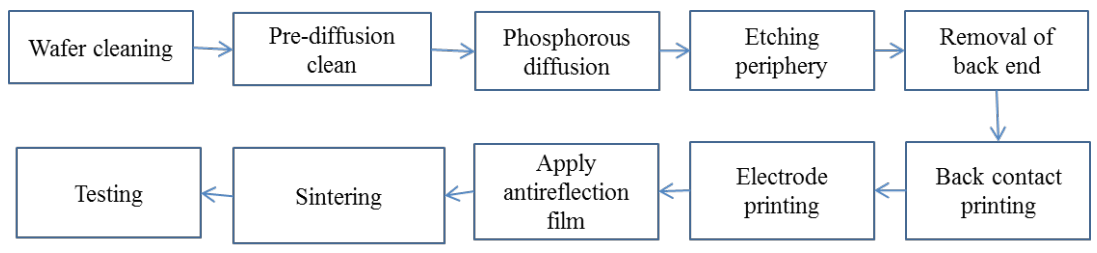

Figure 3.PV solar cell manufacturing process steps.

\section{China Solar Manufacturing Industry}

China's foot print in the value chain exhibits an asymmetry in the industrial chain, where it exhibits poor competence in the front end and in the back end of the solar value chain (Yanget al.(2010)). China imported $95 \%$ of its PV raw materials due to lack of advanced technologies to produce crystalline silicon and in the final market of finished solar panels it depends on the foreign markets. Thus both export and import exists in the solar supply chain of China. As pointed out in previous paragraphs, China initially focused its production to the installation needs of USA and Europe.

China today manufactures $18 \%$ of global silicon material while it produces $47 \%$ and $54 \%$ of the global production capacity in the cells and module business. This may arise if it is financed by foreign governments which extended subsidies to China's overseas markets. However this study suspects that there are additional underlying reasons for such results.

Production of high purity polycrystalline silicon has been a bottleneck in the Chinese solar PV industrial chain (Yanget al.(2011)). This being the feedstock of further production steps, it affects the overall production capacity. Since 2009, China's silicon production is seeing serious investments and hence a surge in production, however quality and pollution still persist. As per 2009, still China experienced a shortage of $62.5 \%$ raw materials for ingot production, which were covered by imports.

The increase in silicon production resulted in wafer manufacturing growth at an annual increase of 100\% between 2004 and 2008. One core technology to such process is wafer slicing (or cutting) which aims to cut a long round bar into thin slices of sheets. One way to produce low cost is through making thinner wafer and thereby producers more wafers from a silicon feedstock. For example a reduction of $0.32 \mathrm{~mm}$ to $0.18 \mathrm{~mm}$ was achieved by China domestic solar PV cell manufacturing firm that enhanced production. Such know-how comes from the nearby IC manufacturing industry where the art of slicing wafers is being pursued (Arnaud et al.(2011)). Similarly the art of converting monocrystalline silicon to polycrystalline silicon indicates that China's ingot is getting technologically matured.

The next step is the solar cell manufacturing where China leads to be al-

Journal of Technology Management for Growing Economies, Volume 3, Number 2, October 2012 
most half of the world's producer and has sustained its positions since 2003. For example, as per 2008 the top 10 domestic cell producers accounted for $75 \%$ of the national production. Table 3 and 4 lists leading firms and their capacity and country of origin. The leading cell producing firm being Suntech which accounts to $20 \%$ of the national production. As we discuss about the first generation solar technology (viz., crystalline silicon), China still lags significantly in second generation solar technology (viz., thin film solar cells) compared to USA and Germany.

Further in the production, the solar cells are converted into solar modules, where China has shown clear domination in its know-how to incorporate clusters of PV cells into a unit namely module encapsulation. In 2009, China's share in the world's module was around 59\%. This was possible due to its strength in equipment manufacturing that enhanced from the IC manufacturing industry, due to its relatively lowest technological threshold and demands for unskilled labour and low labour costs, thereby was being handled by small medium sized business, and hence good business growth in the whole PV industry.

According to CASolar ${ }^{6}$, the solar panel prices from China have been decreasing significantly ${ }^{7}$ as shown in Fig. 4. Similar price reduction is seen at solar cell and module components which form a part of the solar panel system. Accordingly the top ten firms of the global solar cell manufacturers shows that seven out of the ten top positions have been taken up by China domestic solar manufacturers (as per 2011). Similarly in solar module manufacturing among the top ten positions in terms of production capacity (in MW) eight indigenous Chinese firms have overtaken their global coun terparts.

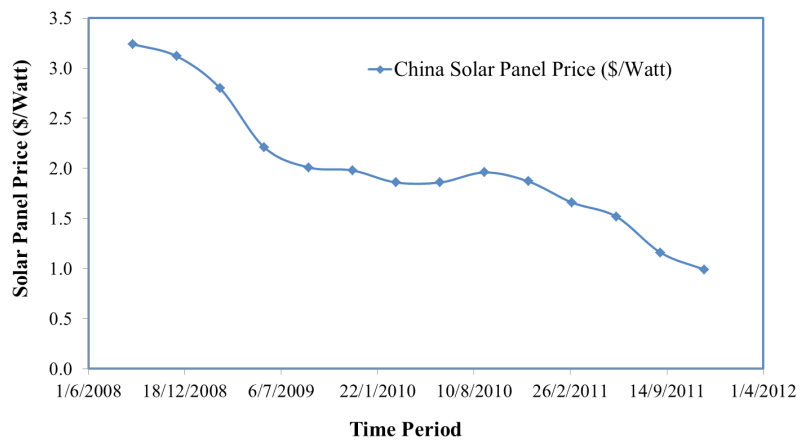

Figure 4: Declining trend in China solar panel prices ${ }^{a}$

${ }^{a}$ US\$/Watt at current prices (2008Q2-2012Q2).

Source: CASolar ${ }^{6}$ (2012).

Journal of Technology Management for Growing Economies, Volume 3, Number 2, October 2012
Fusing East and West 
Srikanth, N.

Watanabe, $\mathrm{C}$.

Table 3 Top 10 global solar cell manufacturers in China (2011)

\begin{tabular}{|l|c|c|}
\hline Firm & Capacity(MW) & Country \\
\hline Suntech & 2400 & China \\
\hline JA Solar & 2100 & China \\
\hline Trina & 1900 & China \\
\hline Yingli & 1700 & China \\
\hline Motech Solar & 1500 & Taiwan \\
\hline Gintech & 1500 & Taiwan \\
\hline Canadian Solar & 1300 & China \\
\hline Neo Solar Power & 1300 & Taiwan \\
\hline Hanwha Solar One & 1100 & China \\
\hline Jinko Solar & 1100 & China \\
\hline
\end{tabular}

Source: Energytrend (2011) .

${ }^{a}$ www.energytrend.com

Table 4 Top 10 global solar module manufacturers in China (2011)

\begin{tabular}{|l|c|c|}
\hline \multicolumn{1}{|c|}{ Firm } & Capacity (MW) & Country \\
\hline Suntech & 2400 & China \\
\hline LDK & 2500 & China \\
\hline Canadian Solar & 2000 & China \\
\hline Trina & 1900 & China \\
\hline Yingli & 1700 & China \\
\hline Hanwha Solar One & 1500 & China \\
\hline Solarworld & 1400 & Germany \\
\hline Jinko & 1100 & China \\
\hline Suneeg & 1000 & China \\
\hline Sunpower & 1000 & USA \\
\hline
\end{tabular}

Source: Energytrend (2011) .

${ }^{a}$ www.energytrend.com

Table 5 give a critical analysis of the asymmetry in the value chain of China's PV manufacturing where the bothends have been relatively weak where at one end it imports its raw material and purely depends on exports. This draws clear attention to understand the roots behind the conspicuous strength in cell and module manufacturing.

Journal of Technology Management for Growing Economies, Volume 3, Number 2, October 2012 
Table 5 China's manufacturing competitive advantage in Solar PV production chain

\begin{tabular}{|l|l|l|l|l|l|}
\hline \multicolumn{1}{|c|}{$\begin{array}{c}\text { Industrial } \\
\text { chain }\end{array}$} & \multicolumn{1}{|c|}{ Silicon } & Ingot/ Wafer & \multicolumn{1}{|c|}{ Cells } & Modules & PV arrays \\
\hline Features $^{a}$ & $\begin{array}{l}\text { High energy } \\
\text { consump- } \\
\text { tion; } \\
\text { Poisonous } \\
\text { emissions }\end{array}$ & $\begin{array}{l}\text { Decrease in the } \\
\text { thickness of } \\
\text { silicon wafers is } \\
\text { an effective way } \\
\text { to reduce cost of } \\
\text { PV cells }\end{array}$ & $\begin{array}{l}\text { Large } \\
\text { scale pro- } \\
\text { duction } \\
\text { is most } \\
\text { important }\end{array}$ & $\begin{array}{l}\text { Fierce com- } \\
\text { petition } \\
\text { Labour- } \\
\text { intensive }\end{array}$ & $\begin{array}{l}\text { Comprehen- } \\
\text { sive use of } \\
\text { combined } \\
\text { technologies } \\
\text { is required. }\end{array}$ \\
\hline Capital $^{a}$ & $\begin{array}{l}\text { High } \\
\text { investment } \\
\text { and long } \\
\text { payback }\end{array}$ & $\begin{array}{l}\text { Medium invest- } \\
\text { ment }\end{array}$ & $\begin{array}{l}\text { Medium } \\
\text { investment }\end{array}$ & $\begin{array}{l}\text { Low } \\
\text { Investment } \\
\text { \& short } \\
\text { payback }\end{array}$ & $\begin{array}{l}\text { Low } \\
\text { Investment } \\
\text { \& short } \\
\text { payback }\end{array}$ \\
\hline $\begin{array}{l}\text { Technology } \\
\text { barrier }\end{array}$ & High & Medium & Medium & Low & Low \\
\hline No. of firms ${ }^{c}$ & 70 & 178 & 335 & 234 & 700 \\
\hline $\begin{array}{l}\text { Manufacturing } \\
\text { in China }{ }^{a}\end{array}$ & Weak & Medium & Strong & Strong & Strong \\
\hline
\end{tabular}

Sources:

${ }^{a}$ China Solar PV Industry Report, 2008-2009 All China Marketing Research, ACMR, p. 1.

${ }^{b} Y a n g, M ., Y u, H .$, Solar photovoltaic Industry in China, China's Industrial Development in the $21^{\text {st }}$ century, p. 195.

${ }^{c}$ No. of firms computed from ENF website (as of 2011).

\section{China solar manufacturing competitiveness}

The five principle reasons for the price reduction in silicon cell and module is generally seen from declining silicon prices, competition from thin film products, government incentives, increasing economies of scale and efficiency, and oversupply. Apart from these factors, yet China shows evidence of lower manufacturers' price compared to their global competitors and hence China's domestic solar PV manufacturers have a cost advantage.

The top tier Chinese cell and module manufacturers have shown a cost advantage of 18 and 30 percent compared to the USA counterparts (Gordon et al. $\left.(2012)^{8}\right)$. According to GTM research analyst Shyam Mehta ${ }^{9}$, the cost reduction exhibited by China manufacturers than the USA manufactures is 25 to 30 percent in 2012 and Rob Wanless, Director of Business development, Solon Corporation, mentions China manufacturers' solar panel price is US $\$ 1$ per watt, while USA manufactures' for similar technical specifications is US $\$ 1.20$ to US $\$ 1.30$ per watt. From the view of China manufacturers, China has a cost advantage of US $\$ 0.20$ per watt on modules and US $\$ 0.10$ per watt (Gordon Brinser et al.(2012)). 
Srikanth, N.

Watanabe, C.
According to Alan Goodrich (Solar PV expert at NREL) comparing the case of manufacturing the solar cells from China such as Suntech and further shipping to USA through sea route and land route to reach the solar farm in arizona, verus purely manufacturing still exhibits a 5 percent advantage(Goodrich et al.(2011)). This success they attribute to purely foreign direct investment in terms of capital investment and knowledge transfer into China. Secondly Gordon Brinser et al.(2012) claims the vertical integration and placing the plants, such as keeping the cell manufacturing in China and placing the module manufacturing (which purely involves assembly) closer to the end user (such as solar farm) turns out to be at best cost advantage. For example, Suntech adopts the above methods to have a cost advantage for its 300 MW solar farm in Arizona. However these two studies fail to tell why the China's advantage arises in the cell and module manufacturing in the China's domestic firm such as Suntech versus that of the US based manufacturer like Solarworld, hence the present research investigates the additional advantages in this research.

Section 2 puts forth the hypothesis and constructs an analytical framework and demonstrates through empirical and qualitative analysis about technology spillover from domestic semiconductor firms and global solar firms to the domestic solar firms of China. Section 3 provides interpretation of the resultsand presents micro evidences of technology spillover at industry level using patent data and supplements with the case of Suntech solar PV manufacturer's evolution and developments.Section 4 briefly summarises the key findings of the analysis and presents policy implications.

\section{ANALYTICAL FRAMEWORK}

\section{Hypothesis}

Prompted by the foregoing observations, the following hypotheses are postulated:

Conspicuous strength emanates from the institutional sources that arose the China's solar industry in recent years. Interaction between indigenous semiconductor industry ("East") and newly emerging solar industry in absorption of global best practices ("West") thereby fusion between them were the reasons for conspicuous strength.

The fusion can be achieved through joint work between industry's intensive effort in learning global best practices for exploring new business and government's catalytic role for the attainment of decarbonisation society for nation's sustainability.

\section{Analytical Model}

Based on the discussion in the preceding section numerical analysis was conducted by utilizing two models, as follows:

Journal of Technology Management for Growing Economies, Volume 3, Number 2, October 2012 
(1) Evidence of spillover effects from external knowledge stock of rel evant industries.

It is generally demonstrated that the production prices of the solar cell depends on the actual production and the internal resources of a firm (Labor and capital). In addition, the process innovation that arises from the indigenous efforts along with a capability to assimilate the external knowledge stock enhances the overall production and thereby the production price of the solar cell.

$$
P_{r}=F\left(Y, L, K, T, T_{s}\right)
$$

where $P_{r}$ : solar cell production prices,

$Y$ : actual production of solar cells,

$L$ : number of employees in the solar cell firms,

$K$ : capital stock in solar cell firms,

T: gross technology stock (by terms of TFP) of solar cell firms, and

Ts: technology stock relevant to solar cell production.

Taylor expansion to the secondary termleads to the following analytical model:

$$
\begin{aligned}
& \ln P_{r}=A+\alpha_{1} \cdot \ln Y+\beta_{1} \cdot \ln T+\gamma_{1} \cdot \ln T_{s}+\delta \cdot \ln L+\varepsilon \cdot \ln K+\alpha_{2} \cdot \ln Y \cdot \ln T+\alpha_{3} \cdot \ln Y \cdot \ln L+ \\
& \alpha_{4} \cdot \ln Y \cdot \ln K+\beta_{2} \cdot \ln T \cdot \ln T_{S}+\beta_{3} \cdot \ln T \cdot \ln L+\beta_{4} \cdot \ln T \cdot \ln K+\gamma_{2} \cdot \ln T_{S} \cdot \ln L+\gamma_{4} \cdot \ln T_{s} \cdot \ln K+ \\
& \delta_{1} \cdot \ln L \cdot \ln K
\end{aligned}
$$

where $A$ : coefficient, $\alpha_{i}, \beta_{i}, \gamma_{i}$ and $\varepsilon_{i}(i=1$ to 4$)$ coefficient corresponding to the respective explanatory variables.

The evidence of the spillover can be further confirmed by checking the magnitude of the derivative as depicted by equation (3). When the magnitude is negative it demonstrates that the external technology stock relevant to solar cell production provides spillover effects on China solar cell firms' for enhanced production to achieve cost effective prices.

$$
\partial \ln P_{r} / \partial \ln T_{s}=\gamma_{1}+\beta_{2} \cdot \ln T+\gamma_{2} \cdot \ln L+\gamma_{4} \cdot \ln K
$$

(2) Evidence of spillover effects from global solar MNC's knowledge stock.

Solar cells production can be depicted by the following function:

$$
Y=F\left(L, K, T_{i}, T_{g}\right)
$$

where $T_{i}$ : Technology stock of solar cell firms by terms of patents, and 
Srikanth, N.

Watanabe, C.

$T_{g}$ : Technology stock of global solar MNC firmsby terms of patents.

Gross technology stock can be expressed in terms of $T_{i}$ and assimilated spillover technologyz. $T_{g}$ (Watanabe et al.(2000))as follows:

$$
\mathrm{T}=\mathrm{T}_{\mathrm{i}}+\mathrm{z} \cdot \mathrm{T}_{\mathrm{g}}
$$

where z: assimilation capacity.

Thus equation (4) can be depicted by the following Cobb-Douglas type function:

$$
Y=A \cdot L^{\alpha} \cdot K^{\beta}\left(T_{i}+z T_{a}\right)^{\gamma}
$$

where $A$ : scale factor and, $\alpha, \beta$ and $\gamma$ : elasticitiescorresponding to the respective explanatory variables.

Taking logarithm of equation(6), following linear functioncan be obtained:

$$
\ln Y=\ln A+\alpha \cdot \ln L+\beta \cdot \ln K+\gamma \cdot \ln T_{i}\left(1+z \cdot T_{g} / T_{i}\right)
$$

When $1>>z .\left(T_{g} / T_{i}\right), Y$ can be approximated as follows (Watanabe et al., 2000):

$$
\ln Y=\ln A+\alpha \cdot \ln L+\beta \cdot \ln K+\gamma \cdot \ln T_{i}+\gamma \cdot z \cdot\left(T_{g} / T_{i}\right)
$$

Assimilation capacity can be identified from equation (8) as

$$
z=z \cdot \gamma / \gamma
$$

\section{Data Construction}

The data of the dominant domestic solar firms of China involved in solar cell and module manufacturing included details on labour, capital, production, prices, registered year and market share as listed in Appendix A1. The firms' technology sources were investigated either from joint ventures or directly funded from foreign funds. Additional information included in looking into their official web links to access their annual reports and obtain product types, models, capacity and yearly growth. Similarly, data was collected for the top ten global solar firms in terms of market share, labour, capital, production, price and other firm details.

\section{Empirical Findings}

Facing a paradigm change from a fossil fuel based society towards a decarbonisation society, China's industrial institutions has evolved a conspicuous strength in solar PV manufacturing by producing useful components in the value chain and initially targeting export market and further

Journal of Technology Management for Growing Economies, Volume 3, Number 2, October 2012 
diffusing into its domestic installation. This approach has aided the evolution and growth of China's leading domestic solar PV firms.

Table A1 summarizes the current leading domestic solar firms involved in solar cell and module manufacturing.

The top 74 domestic solar PV cell and module manufacturers form the major share of cell and module manufacturing that amounted to a actual manufacturing capacity of 30325 MW which exceeded world solar panel production in 2011 which amounted to $29534 \mathrm{MW}$.

(1) Evidence of Technology spillover from Semiconductor industry

Taking the top 74 solar PV cell and module manufacturers production which amounts to a total capacity of $30375 \mathrm{MW}$ in year 2011 which equates closely to the world solar PV installation in 2011 (as per Table1), it shows the accelerated conspicuous indigenous strength building occuring by the extraneous knowledge spillover from the semiconductor industry. Hence their knowledge assimilation aspects from the existing semiconductor industry was determined as per equation (2):

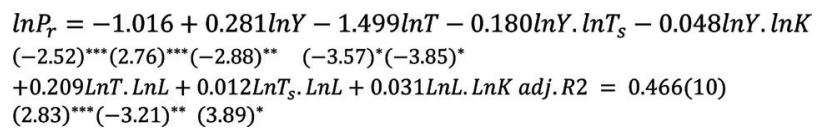

$*$, ** and $* * *$ indicates significant at the $1 \%, 3 \%$ and $5 \%$ level, respectively.

Partial differentiation of $P_{r}$ with respect to $T_{s}$ leads to elasticity of spillover technology to production price, as follows:

$$
\partial \ln P_{r} / \partial \ln T_{s}=-1.499\left(\partial \ln Y / \partial \ln T_{s}\right)-0.0148 \ln T+0.012 \ln L
$$

Utilizing this relation the sensitivity of price with respect to spilled-over technology stock for the different firms under this study was computed (refer Table A1). Fig. 5 demonstrates the elasticity of spillover of different firms (1 to 74)in the order of increasing market share. Results shows that the negative magnitude of the sensitivity which confirms that the knowledge spillage for each firm from semiconductor industries is positive. Comparing the magnitude between the firms, it is obvious that the first ten firms exhibits increased assimilation capability as compared to the rest of the domestic which implies the importance of spillage to achieve decreased price. 
Srikanth, N.

Watanabe, $\mathrm{C}$.

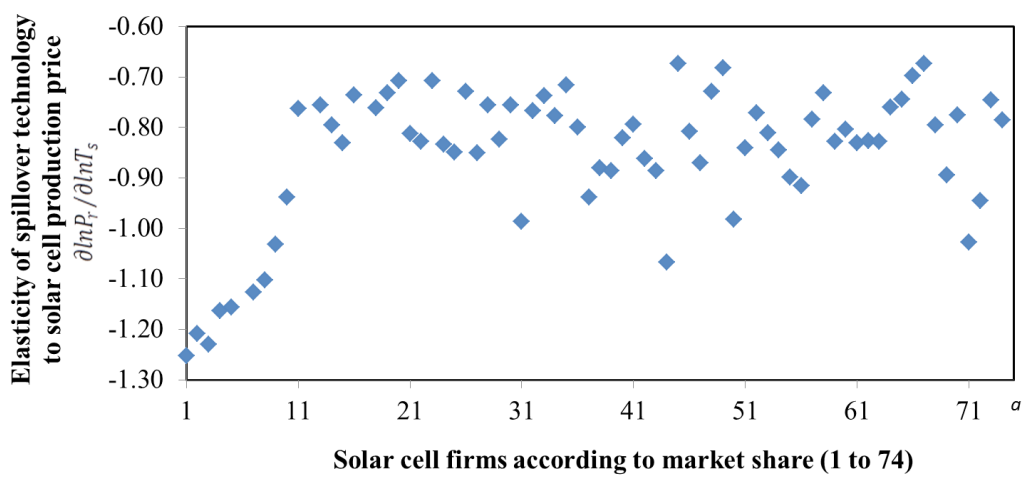

Figure 5: Effects of technology spillover from semiconductor industry to China's Indigenous 74 solar cell firms (2011).

${ }^{a}$ Numbers indicate firms examined in accordance to their market share (No.1 is the largest market share while No.74 is the smallest market share, see Table A1).

\section{Evidence of Technology Spillover from Global Solar Firms}

Taking the top 23 solar PV cell and module manufacturers among the 74 domestic China solar cell and module manufacturers, their manufacturing output amounted to $14340 \mathrm{MW}$ which equates to $~ 50 \%$ of China's manufacturing output in 2011. Hence their technology stock build-up is of importance from knowledge assimilation aspects from the global solar firms were investigated as per equation (8):

$$
\begin{aligned}
& \ln Y=-1.557+0.237 \ln L+0.023 \ln K+0.041 \ln T_{i}+0.010\left(\frac{T_{g}}{T_{i}}\right) \quad \text { adj. } \mathrm{R}^{2}=0.872 \\
& (-17.17)^{*}(2.91)^{*}(1.02)^{* * *}(1.48)^{*}(37.62)^{*}
\end{aligned}
$$

$*$ and $* * *$ indicates significant at the $1 \%$ and $5 \%$ level, respectively.

By equation (9) assimilation capacity $z$ can be identified as 0.24 of spillover technology from global solar firms.

\section{Qualitative Analysis Results: Technology Transfer Modes to China Solar Industry}

Technology learning and spillover are key to the evolution of new industry. Technology transfer includes all mechanisms by which a domestic firm can acquire useful knowledge from a foreign firm on the critical aspects of the solar value chain's components and system level (Maskus 2004). Based on the technology literature various knowledge transfer modes could exist and were observed within the Chinese solar industry:

1. Licensing: Codified knowledge and exclusive right to exploit is sold by

Journal of Technology Management for Growing Economies, Volume 3, Number 2, October 2012 
one party to another, Example Australia PV Science and Engineering Co., helped transfer solar cell manufacturing technology to Jingao Solar Co., Ltd., in MAY $2005^{10}$.

2. Movement of capital through FDI: Ownership of a productive asset by a foreign entity into the host country. Example, the equipment that is imported is pretty matured for crystalline silicon technology which is a dominant technology when China evolved the solar PV manufacturing industry,

3. Movement of people through migration, travel and foreign education of students and workers. Example: Suntech CEO was educated in New south wales (NSW) and later when he setup this firm in China he setup collaboration with NSW and has taken up as a visiting professor at NSW,

4. Diffusion through media and the internet of disembodied knowledge such as access to international patent database, competitor website and international scientific articles,

5. Integration of benefits into global value chains from foreign technology transferred within the supply chain (Fu, Pietrobelli and Soete 2011), and

6. Knowledge spillover from other domestic related industry through labour mobility.It is empirically proven that in China labour mobility during inter-industry results in salary hike and this is an incentive for such knowledge transferor.

\section{FDI SUPPORTED KNOWLEDGE TRANSFER}

Among the various modes, FDI supported knowledge transfer can be expected as a dominant factor. It is widely understood that knowledge from technically advanced countries increasingly transcends national boundaries and contributes to the domestic technological development. FDI plays a significant role in the country's economy and China because of skilled labour availability exhibits a good absorbability and productivity. For example FDI increased from 0.9 billion in 1983 to US\$ 74.8 billion in 2007 and have been instrumental in developing healthy electronics industries as listed in Table A4. Productivity spillover is observed as one of the benefits of FDI. However as pointed out in Table 6, the presence of FDI in all the leading Chinese solar firms is minimal.

Among the world's 15 largest solar cell or module producers in 2010, nine firms operate in China and two had foreign direct investment. Canadian Solar was founded in 2001 and has seven wholly-owned manufacturing subsidiaries across China. JA Solar was founded in 2005 as a joint venture between the 
Srikanth, N.

Watanabe, C.

JingLong Industry and Commerce Group Co., Ltd., the Australia PV Science \& Engineering Company, and the Australia Solar Development Company. Hanwha SolarOne was initiated by Korean Hanwha Group by acquiring in 2010 the China's Solarfun Power that was originated in 2004. The two companies that were either wholly owned subsidiary of a foreign company or as a joint venture with a foreign company was JA Solar and Canadian Solar. JA Solar was a late entrant to the Chinese PV industry, coming well after home-grown firms like Suntech, Yingli, Trina, and Jiawei Solar China. While Canadian Solar was founded in 2001, there is no indication that its foreign counter part helped to drive enough technology transfer to fuel the growth of China's solar industry. Thus FDI in the traditional sense of technology transfer, and knowledge spillover, has not been a significant factor in the development of China's solar cell and module manufacturing industry and has been a predominantly home-grown industry.

Table 6: Technology source of China's top 10 solar PV firms

\begin{tabular}{|l|c|c|}
\hline \multicolumn{1}{|c|}{ Chinese Firm } & Starting year & FDI-Joint Venture links \\
\hline Suntech & 2001 & None \\
\hline Yingli & 1998 & None \\
\hline Jingao & 2005 & Australia \\
\hline Solarfun & 2004 & None \\
\hline Sunenergy & 2004 & Australia \\
\hline Canadian solar & 2001 & Canada \\
\hline Ningbo Solar & 2003 & None \\
\hline Trina solar & 1997 & None \\
\hline Jiangsu Jiaoseng & 2004 & None \\
\hline
\end{tabular}

\section{Technology learning, knowledge spillover from previous industries}

The dominance of the China's solar power industry is generally being attributed to: (1) the cheap labour availability of skilled members (2) availability of the matured high end equipment which ensures same silicon based solar panels with high quality as that of the international manufacturers. A closer study shows China builds its factories faster in setting up the necessary supply chain. For example, by 2006, Suntech power of China was manufacturing a million solar panels in an annual year. Today China overall manufactures about 50 million solar panels and over half the world capacity in $2010^{11}$ and thus it has exhibited a doubling the production capacity roughly every year. The aggressive scaling of production factories are attributed to the labour availability of other 
complimentary industries like construction industries. Alongside with its production, it constantly craves for new innovation to enhance its efficiency of the product. Traditionally China set forward to scale their production in standard technology but as supply exceeds demands, to stay afloat globally it has to constantly adopt new innovations to reduce cost and enhance product performance.

To understand the reasons for the availability of skilled labour once needs and West to look into the possible knowledge spillage. Knowledge is seen as a public good ((Nelson (1959),Balzat et al.(1962)). Spillover is a positive externality due to the public nature of knowledge.Spillovers arise if firm A can benefit from firm's B R\&D activity without sharing the R\&D costs of B (Branstetter (1998)). For a new industry to tap existing patents from relevant industries may be a good leverage: "By technological (or R\&D) spillovers we mean that a firm can acquire information created by others without paying for that in a market transaction" (Grossman \& Helpman, (1991)). Many researchers have studied the spillover due to the geographic proximity such as Anselin et al.(2000), Jaffeet al.(1993); while trade related FDI related spillover has been studied by Grossman \& Helpman (1991) and Kinoshita (2001).

Assimilation of existing knowledge from relevant know-how along with technology transfer have been key in the indigenous innovation and thereby the world dominance of the solar PV manufacturing in China. Know-how refers to any methods, techniques, processes, discoveries, inventions, innovations, unpatentable processes, technical information, specifications, recipes, formulae, designs, plans, documentation, drawings, data and other technical information and identified in a tangible form.

Among the various institutions private firms have been the major force in pursing $\mathrm{R} \& \mathrm{D}$ and process innovation to become cost-competitive. This has been favoured by the National innovation system (NIS) that is composed of the private firms, government agencies, foreign subsidiaries, their supply chain, academia and research institutions and their actors and various linkages (Balzat et al.(2004)).

Next absorptive capacity has been addressed on human capital as instrumental in productivity (Griffithet al.(2003) and (2004), Miller et al. (2000)). In the case of China, the absorptive capacity through different channels for knowledge spillovers such as R\&D, FDI and exports have been through the right calibre labour intake into firms that they have employed such thattheir interaction effects have resulted in the increased firm production. In such a 
Srikanth, N.

Watanabe, C.

view, foreign firms have aided as an active player in the NIS through knowledge transfer, knowledge creation and through participation of competition. On an average, foreign invested firms (MNEs) have demonstrated the real manufacturing procedure as a predecessor to the domestic firms, such that it was easy for the domestic firms to mimic and practice. For example, the developments of some industries in China such as integrated circuits, automotive have been fuelled by the foreign invested enterprises. The presence of these MNEs helped to fuel development of indigenization in China through technology transfer and rapid diffusion of know-how. The spillover takes place through (a) inter firm mobility of workers and managers (b) industry supply side and customer side relation (c) exports by multinational affiliates (d) utilization of supply chain actors from other relevant industries. Blakeet al.(2009), study on 998 Chinese manufacturing firms showed labour transfer between foreign invested firms and local firms affect the productivity of local firms positively when they employ foreign trained workers. Their results confirmed absorptive capacity of local firm is important for spill over to occur and to increase productivity.

Productivity spillover takes place when worker or manager in foreign MNC resigns and joins a domestic firm or starts their own firm specific to that industry. Thereby they exert a positive impact in the industry and the foreign firms in terms of productivity. Fosfuriet al.(2001) showed that the multinational had to increase salary to retain worker after they trained him, else a technology spillover may result to a local firm.

One possible knowledge source can be its own domestic know-how by studying the technology similarities between industries which is one observation that can be made between the new solar industry and existing semiconductor industry in China. Their technology similarity can be observed by closely observing the process plan of the silicon material as shown in below figure.

China solar manufacturing has been essentially dominant in C-Si technology compared to TF-Si technology. The dominance in the first generation C-Si silicon technology may be due to rich source of raw materials and technology maturity; however one reason that can be postulated is the history of success in China's semiconductor industry even with complex technological nature. Figure 6 shows how the semiconductor and solar industries are linked through the silicon value chain.

Journal of Technology Management for Growing Economies, Volume 3, Number 2, October 2012 


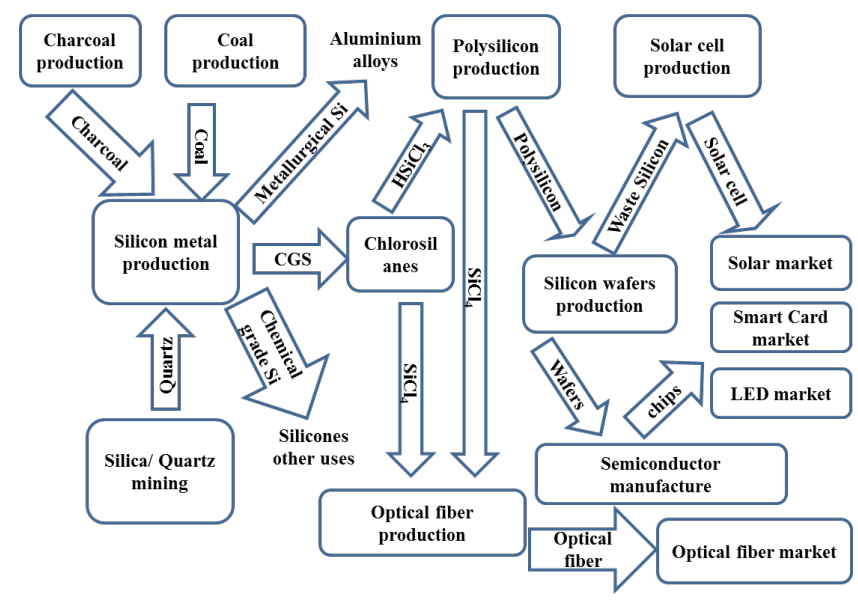

Fusing East and West

Figure 6.The production chain for high-purity silicon and its use in semiconductor, solar cell, smart card, LED and optical fiber manufacturing.

To understand why China chooses to focus on the first generation Solar PV cell and module manufacturing we could investigate its industrial history. China has been successful in the electronic industry in 1990s and has made significant progress as seen in Fig. 7. Hence there is significant evidence of its knowledge accumulation in the process technologies that are required for electronics manufacture (Tilman et al.(2008) and Liu X., (2001)). Table A4 lists the various electronics industries productivity and capital per capita. The production function of the Chinese electronic industry was studied earlier ${ }^{12}$ which shows that the industry has good productivity due to skilled labour. Such healthy presence has exhibited a strong growth in revenue in both semiconductor manufacturingindustry and integrated circuit manufacturingindustry (which is also called semiconductor packaging industry).

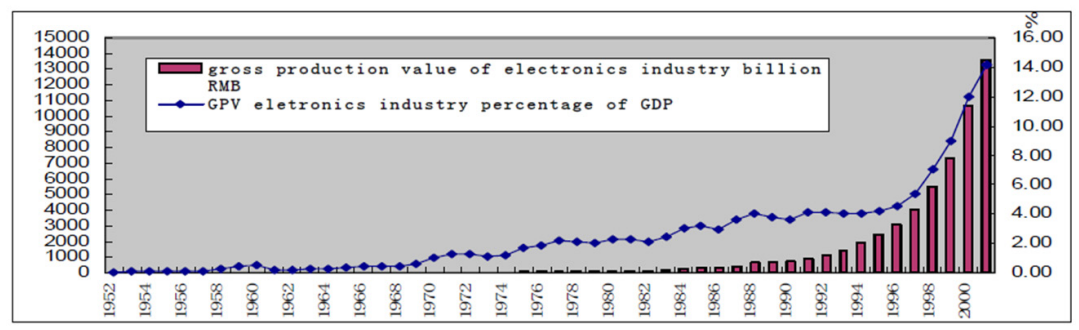

Figure 7.China's 50 year electronics industry growth

Source: Xinxin Kong, National Research Center for Science and Technology for Development (NRCSTD). 
Srikanth, N.

Watanabe, C.

24
Table 7: Annual revenue of semiconductor and IC industries in China (2000-2010).

\begin{tabular}{|c|c|c|}
\hline Year & Semiconductors & Integrated circuit (IC) \\
\hline 2000 & 14.4 & 11.4 \\
\hline 2001 & 17 & 13.8 \\
\hline 2002 & 21.4 & 17.7 \\
\hline 2003 & 30.7 & 25 \\
\hline 2004 & 43.4 & 8.3 \\
\hline 2005 & 56.5 & 46.4 \\
\hline 2006 & 71 & 59.5 \\
\hline 2007 & 88.9 & 73.9 \\
\hline 2008 & 103.8 & 85.9 \\
\hline 2009 & 101.2 & 18.1 \\
\hline 2010 & 132 & 108.6 \\
\hline
\end{tabular}

Source: Price Waterhouse ${ }^{b}$ (2011).

${ }^{a}$ Billion US\$ at current prices.

${ }^{b}$ www.pwc.com

According to NREL analysis US manufacturing facility is automated as compared to China manufacturing facility which is more labour based, yet Chinese products have demonstrated 18 to 30 percentages increases ${ }^{13.14}$. This possibly shows that the inducted skilled force and their internal training can meet the final customers of the solar production value chain. This evidence of quality production that meets the end requirement shows that the technology transfer (1) through equipment manufacturers, (2) through licensing and research collaboration, and (3) know-how from the Chinese diaspora have been well absorbed and assimilated into useful process capability of solar manufacturing. For example, technology transfer from American, German and Swiss equipment makers has allowed Chinese manufacturers to initiate and scale the solar production lines into their factories in a short time span (Gordon Brinser et al.(2012)). Thus it is convincing that China's labour force has acquired skills from other relevant industries and foreign direct invested MNEs.

\section{DISCUSSION}

Moving towards a renewable energy adoption, China has coevolved a 
conspicuous Industrial strength to evolve solar PV manufacturing ability into order the growth and adoption and to evolve a new export market to cater the world needs. In a very short time span as seen in Fig. 1, it exhibited a rampant growth in production capabilities. Table A1 summarizes current state of China's leading solar PV manufacturing by order of real production, market share and price in 2011.

\section{Comparative Advantages}

A broad investigation may show that China has the following advantages:

(1) Advantage of scale

(2) Advantage of vertical integration

(3) Availability of cheaper skilled labour.

\section{(1) Scale}

China's core advantage in cell manufacturing can be seen to arise from scale and vertical integration. Comparing a $60 \mathrm{MW}$ plant in USA and a $2000 \mathrm{MW}$ plant in China shows that 10 percent reduction in material cost and 50 percent reduction in equipment cost from Chinese equipment vendors, due to supplier leverage and captive production strategies (NREL report, Goodrich et al., 2011).

According to Rob Wanless, Director of Business development, SOLON Corporation, most of the facilities in China of the leading manufacturers have larger facilities than the USA manufacturers (Gordon Brinser et al.(2012)). The typical top tier manufacturing plant in China produces annually about 500 to $1000 \mathrm{MW}$ which is higher than the typical manufacturing plant capacity of USA which ranges between 40 to $100 \mathrm{MW}$. Thus according to Melaine Hart, Policy analysts for Chinese Energy and Climate policy at the centre of American progress, China gets advantage as being a manufacturing powerhouse (Hart, 2011).

According to Goodrich of NREL ${ }^{15}$ cost comparison of cell manufacturers shows:

(i) US $60 \mathrm{MW}$ automated plant shows US $\$ 0.89$ per watt.

(ii) China $60 \mathrm{MW}$ plant shows US $\$ 0.85$ per watt.

(iii) China 2000 MW plant shows US $\$ 0.82$ per watt.

(iv) China 2000 MW plant with discounted equipment US\$0.80.

(v) China $2000 \mathrm{MW}$ plant with discounted materials US $\$ 0.73$.

Thus purely comparing a $60 \mathrm{MW}$ manufacturing plant of China versus USA
Fusing East and West 
Srikanth, N.

Watanabe, $\mathrm{C}$.

shows a minimum of 4.5 percent which is primarily due to low cost of relevant skilled labour. Adding the advantage of scale and vertical integration and domestic equipment and materials supply, Chinese cell manufacturers show an 18 to 20 percent manufacturing cost advantage.

\section{(2) Vertical Integration}

The top tier Chinese solar manufacturers also aim to benefit from vertical integration. For example, manufacturing both cells and modules helps in manufacturer's economies of scale.

\section{(3) Availability of cheaper skilled labour}

Published literature more relates production to the resources availability of a firm (viz., labour, capital and technology stock). For example, as per year 2011, labour rate in China solar work force costs US\$2.13 per hour as compared to USA work force where it would be around US\$13.33 per hour, similarly a manufacturing engineer annual salary is US $\$ 8,171$ in China versus a similar capable engineer's annual salary of US\$75,110 in USA (Goodrich et al.(2011)). Thus for 500 MW capacity of Cell and Module facility, a China factory has 1492 employees and 508 employees, respectively, as compared to a USA factory where it is 296 and 104 employees, respectively. The difference is attributed mainly to the automation in the manufacturing. Based on the export acceptance record by the West in the recent years, the quality of the Chinese solar panels can be deemed to be acceptable as that of the West's solar products, since they have been swappable in a final solar PV project, and can infer that the labour supply to the China solar factories have met the automated factory quality of USA solar factories, possibility with the necessary job based trainings and equipment and tools. However it interests us that how such apt labour force gets supplied to the China's solar industry is scalable in number in the short time span.

Researchers have identified the importance of tacit knowledge (or personal knowledge) in addition to the explicit form of knowledge that is available in the form of patents and international journal papers.Also literature shows the importance of externalities as a source of increasing returns and productivity growth. Technology spillovers exist and the R\&D of nearby firms produce positive effects, so that firms could get large benefits from spillover (Griliches (1998) and Anon (1998)). These could come into a firm in the form of skilled labour hiring and training, use of firms of related industries' supply chain, manufacturing best practices that are borrowed from other related industries, etc. This presence of $R \& D$ spillovers result because the technology distance

Journal of Technology Management for Growing Economies, Volume 3, Number 2, October 2012 
(Jaffe (1986))between the firms that generates the spillover and the receiver is short. From such a view, we find that semiconductor industry has much technological similarities to solar industry and hence the manufacturing knowhow or the personal knowledge of the labour becomes relevant. Such addition of semiconductor manufacturing trained people to a solar PV manufacturing firm enhances the absorption capacity (the capacity of the receiver to absorb technology from the other sector) and the assimilation capacity (the capacity of the receiver to assimilate and then utilize the technology absorbed from the other sector). The assimilation capacity has a direct impact on the speed of technology adoption and thus ramp up the production capacity of a firm. Fig. 8 clearly relates the role of learning to a whole dynamism in assimilation, innovation emergence, production increase and thereby price decrease of the product.
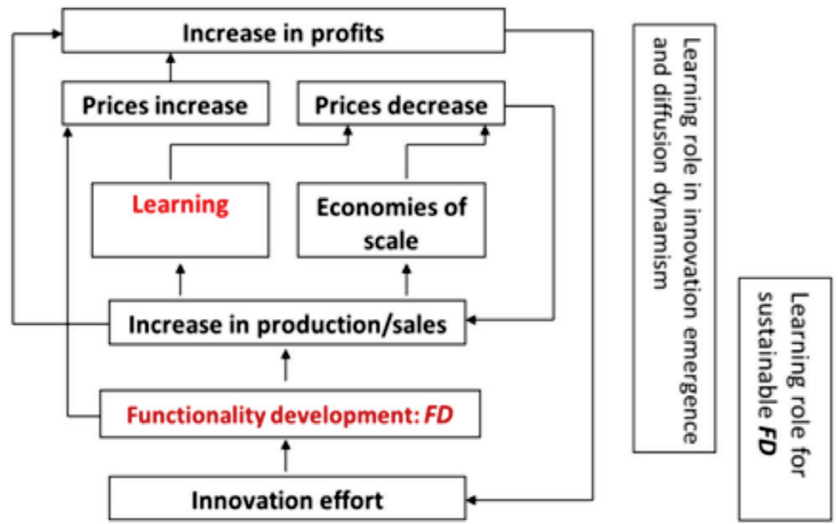

Figure 8.Policy's role in leveraging learning for price decrease

Source: Watanabe et al. (2000).

The empirical findings in this study show that the external knowledge spillovers (FDI and external R\&D) have proved elusive. Additionally, this study has pointed out that the domestic industries' know-how interacts with external technology through an integrated learning process and thereby the TFP (total factor productivity). The study elucidated the structural sources of the high level of conspicuous strength building in China's domestic solar firms. Focusing on their exploitation of semiconductor industry by the assimilation of spillover technology, the motivations of private firms and increases in production and price reduction are identified, particularly in domestic originated firms within a short time span. 
Srikanth, N.

Watanabe, $\mathrm{C}$.

\subsection{Effective Knowledge Spillover Between Industries}

(1) Clear Linkage of Semiconductor and Solar Technologies.

In order to show the micro-evidence in the form of clear linkage between semiconductor and solar patent one could resort to compute the backward citations to show the knowledge spillage. However at this point, the China patent database does not have the backward citation and hence a different method was pursued. Technology can be classified by the International patent classification (IPC) code. Accordingly taking the top 100 technologies based on the IPC-4digit classification for semiconductor industry and comparing with solar industry, the numbers of patents in the two different industries were determined using Thomson database.Among these 100 IPC classes, study shows 80 IPC classes are common between semiconductor and solar industries. Table A5 lists the most common technologies between the semiconductor and solar industryand thenumber of patents originated from the solar and semiconductor industries. To propose that relevant knowledge stock from the semiconductor industry (Pat_IPC_Semicon) has a direct correlation to the knowledge stock in the solar industry (Pat_IPC_Solar), a linear regression can be shown as follows:

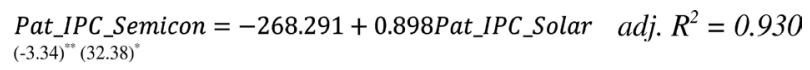

* and ** indicates significant at the $1 \%$ and $3 \%$, respectively.

\section{(2) Evidence of relevant know-how from China's semiconductor industry}

Table 8 lists the top technologies (25 technologies) of China solar industry origin.Analysing these patents' IPC codes it is clear that they are common to semiconductor industry. Thus it is convincing that the know-how of the semiconductor industry is relevant to the inception and growth of the China's solar industry. For example, H01L is a focused technology classification in the field of semiconductor process and figure 9 shows how patents have been growing specifically from China solar firms in the recent years. This exhibits the absorption and assimilation trend within the solar industry from the semiconductor manufacturing know-how and further transforming into useful innovations to support solar manufacturing capability.

Journal of Technology Management for Growing Economies, Volume 3, Number 2, October 2012 
Table 8: Top 25 technologies of China solar expressed as IPC codes (2012)

\begin{tabular}{|c|c|}
\hline IPC ( 4 characters) & Patent Count \\
\hline H01L & 1109 \\
\hline $\mathrm{C} 30 \mathrm{~B}$ & 246 \\
\hline $\mathrm{C} 23 \mathrm{C}$ & 87 \\
\hline $\mathrm{C} 01 \mathrm{~B}$ & 73 \\
\hline $\mathrm{B} 81 \mathrm{C}$ & 60 \\
\hline G02B & 54 \\
\hline B01J & 52 \\
\hline $\mathrm{H} 02 \mathrm{~N}$ & 48 \\
\hline B81B & 45 \\
\hline G02F & 42 \\
\hline H01M & 41 \\
\hline G01N & 41 \\
\hline H02J & 39 \\
\hline C08L & 39 \\
\hline A61K & 38 \\
\hline $\mathrm{C} 03 \mathrm{C}$ & 35 \\
\hline $\mathrm{C} 09 \mathrm{~K}$ & 35 \\
\hline $\mathrm{C} 23 \mathrm{~F}$ & 31 \\
\hline $\mathrm{C} 04 \mathrm{~B}$ & 31 \\
\hline B32B & 30 \\
\hline H01J & 29 \\
\hline B82B & 29 \\
\hline $\mathrm{C} 22 \mathrm{C}$ & 28 \\
\hline $\mathrm{C} 07 \mathrm{C}$ & 26 \\
\hline
\end{tabular}

Taking patent count as one good measure to check how China has a good innovation base in semiconductor industry (Price Waterhouse (2012)) the total number of patents of China (Pat_CS) was regressed to the global number of semiconductor patents $\left(P a t \_G S\right)$ on a cumulative basis.

$$
\begin{aligned}
& \text { Pat }_{C S}=-817.853+0.411 \text { Pat } \\
& (-3.05)^{* *} \text { adj. } \mathrm{R}^{2}=0.980
\end{aligned}
$$

$*$ and $* *$ indicates significant at the $1 \%$ and $3 \%$ level, respectively. 
Srikanth, N.

Watanabe, C.
Thus equation (14) shows China has a healthy growing stream of patents similar to the global semiconductor patents. This shows there is a growing population of innovators in the semiconductor manufacturing field and thus could directly contribute to the manufacturing of solar industry due to the technical relevance as pointed out in earlier paragraphs. Accordingly we see enough reasons for the solar industry to induct the skilled innovators from the semiconductor industry which would have been a key causal reason for the solar industry growth. For example, Figure 9 shows the conspicuous strength of the H01L technology class from the solar industry since 2005 which possibly would have influenced by the presence of relevant knowledge stock and the people stock in the semiconductor industry, due to the common technology relevance as per equation (13).

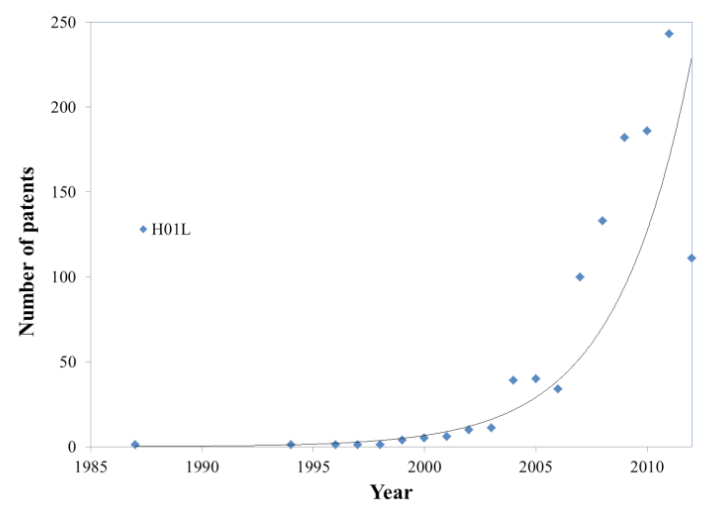

Figure 9: Technology trend in H01L patents from the China solar industry Also a specific keyword search of China's academic publications specific to solar cells (in Engineering Village Database of international journals) shows the important frequently occurring keywords. These give a clue of their research focus. Fig. 10 shows the technical keywords searched specific to the solar cell technology and specific to China. The keywords signify the semiconductor related and process related keywords and that shows the focus of the academic research which is inline to the industry.

Journal of Technology Management for Growing Economies, Volume 3, Number 2, October 2012 


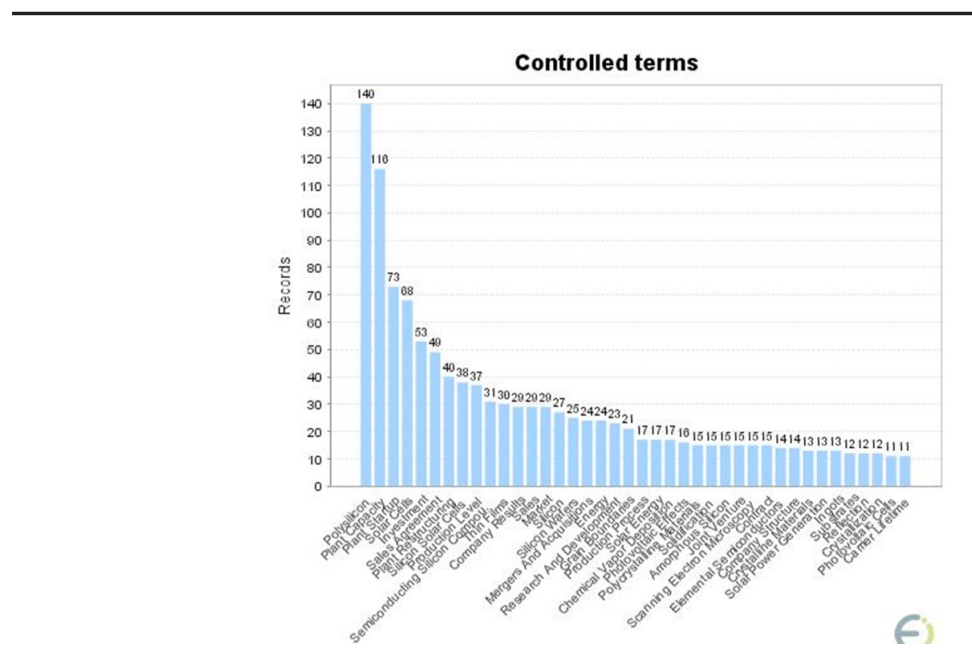

Fusing East and West

Figure 10: Frequent keywords of China originated solar journal papers.

The other promoting reasons for spillover are due to geographic proximity of placing the solar PV industry in the same industrial clusters of semiconductor industry. For example, one of the key presence of the PV industry cluster is in the pearl river delta (Mark Ng 2011) which is known for the semiconductor industry and this has a strong influence in supporting useful labour mobility, capital resources availability and easy identification of supply chain partners for the newly evolving industry.

\section{China's National Subsidy Program}

Subsidies are designed mainly to position China as the global leader in solar manufacturing and essentially not anti-competitive, according to Melaine Hart, Policy analyst for Chinese energy and Climate Policy at the Centre for American Progress. As Robert Petrina, Managing director at Yingli green energy Americas Inc., explained at the ITC conference, "Government incentives for solar projects have been very important in lowering net costs so that the projects can achieve these goals and are implemented. However with incentive levels declining on an unpredictable basis, there has been tremendous pressure to maintain the all in total cost for the projects at levels that continue to be economically viable and drive adoption, preferable, and ultimately without incentive support".

China's government has implemented three important policies to stimulate the solar PV industry; (i) feed in tariffs at national and regional level (ii) the tendering policies (iii) the renewable portfolio standards. The feed in tariffs 
Srikanth, N.

Watanabe, C. accelerates development of the renewable energy infrastructure and the tendering policies are helpful to get competitive prices (Zhen et al.(2011) and Wiser et al.(2002)). Table 9 summarizes the various subsidies and benefits provided by the government to its solar PV production chain.

(i) Rural electrification: Launched in 2002, it aimed to provide electricity to rural areas of China that lacked grid support. By the end of 2005, 721 wind-solar PV power stations were accomplished in west part of China and benefited 1.3 million people.

(ii) Feed in tariffs (FIT): Since 2006, the FIT price was determined as per "cost plus reasonable price" to electricity supply to grid system. The national feed in tariff was put on hold "indefinitely" because the cost of solar power was deemed too high in 2006. But in Aug 2011, the government reinstated the FIT for solar PV industry. In addition, favourable regional subsidies in terms FIT were announced in Zhejiang, Shandong and Jiangsu.

(iii) Golden sun: Launched in 2009, helps to cover 50 to 70 percent of costs to cover utility scale solar projects and other infrastructure and targets towards $1000 \mathrm{MW}$ capacity build up.

China uses the national industrial policy ${ }^{16}$ which is a very clear and specific strategic national policy that directs (and then promotes) the development of a specific industry. The pinnacle of industrial policy in China is the five year plan. China's $12^{\text {th }}$ five year plan clearly articulates the China's goals for the industry. It identifies the solar PV as one of the seven new strategic industries for development. For example China plans to invest US\$100 million to build power projects using Chinese solar panels in 50 African nations(Yang et al.(2010)). In its $11^{\text {th }}$ five year plan it spent US $\$ 309$ billion on energy efficiency and environmental protection measures and today four of the world's five largest photovoltaic solar cell manufacturers are Chinese domestic firms. Over the next five years, the Chinese central and local governments are expected to focus on resources and potential opportunities to further enhance.

The five year plan (2011-2015) developed by Ministry of Industry and Information Technology for solar industry was released in Feb 2012:

(a) Reduce the cost of domestic solar power to 0.8 Yuan (about US \$0.13) per kwh by 2015 and 0.6 Yuan (about US \$0.10) by 2020.

(b) The cost of solar panels in China will drop to 7000 Yuan (about US\$1100) per kw by 2015 and 5000 Yuan (about US \$800) per kw by 2020.

(c) The plan requires China's leading polysilicon manufacturers to reach a 
50000ton annual production capacity (per firm) and leading solar panel makers to reach 5 gigawatts (annually per firm) by 2015 .

(d) China will further help solar companiesincrease their annual sales, with atleast one firm reaching 100 billion Yuan (about US $\$ 16$ billion) in sales and 3 to 5 firms reaching 50 billion Yuan (about US $\$ 8$ billion) in sales by 2015 .

(e) Increase the conversion efficiency of monocrystalline silicon solar cell to 21 percent, polysilicon cell to 19 percent and amorphous silicon cell to 12 percent by 2015 .

(f) Eighty percent of solar equipment and auxiliary materials will be produced domestically.

(g) Thereby it aims to have a minimum installed capacity target of $5 \mathrm{GW}$ by 2015 and $20-30 \mathrm{GW}$ by 2020 such that these large scale capacities is being planned to be placed in deserts.

Such plans that treated solar industry as its strategic focus are the key reasons for the China's solar manufacturers to conspicuously grow from just 2 percent of the market in 2003 to 45 percent in 2010. Other countries such as Germany and Japan have industrial policies too. China support has been on direct manufacturing policies including preferential loans, tax incentives (including sales/value added tax waivers, preferential tax rates, income tax credits, property tax credits, income tax credits, property tax credits, research and development support, central government planning, local and provincial policies, domestic proprietorship requirements and facilities, land and training grants. The other is indirect deployment policies designed to promote demand for photovoltaic solar, direct subsidies, feed in tariff and local and provincial policies.

In 2006, China made key solar PV technologies part of the pillar R\&D support scheme which provided funding for the commercialization of solar technologies by Chinese manufacturers. Recipients include solar PV manufacturers, including Wuxi Suntech, Baoding Yingli green energy, Changzhou Trina Solar ad Xinjiang new energy, and silicon manufacturers including Sichuan Xinguang Silicon and Luoyang Silicon Technologies. The local government provides loans to solar PV manufacturers and not grants that need to be payable. According to Shah (Gordon Brinser et al.(2012)), the Chinese government gave US $\$ 30$ billion to its solar firms by opening a line of credit to aid manufacturing cells and modules. According to online investment magazine Motley Fool, LDK solar has a credit line of US\$8.97 billion, JA solar 
Srikanth, N.

Watanabe, C. has credit of up to US\$.4.42 billion, Suntech has upto US\$7.29 billion,, and Trina solar another US\$4.3 billion. Such financing is difficult to obtain in open market due to least competitive advantage. Thus it is convincing that China government focused between 2006 to 2011 mainly manufacturing and due to evidence of poor domestic installation, it mainly targeted the export market (West) and thereby diffused useful technologies and evolved a new industry in its soil. The economic literature is full of evidence that international trade is an important channel for technology diffusion (Bin $\mathrm{Xu},(2007)$ ).

Table 9: Credits, guarantees, subsidies and grants for solar manufacturers in China ${ }^{a}$

\begin{tabular}{|l|l|}
\hline Features & National Provincial and Local \\
\hline Domestic Proprietorship required & Yes \\
\hline Sales/value added tax waiver & Yes \\
\hline Property tax credits & Not applicable \\
\hline Subsidized cost of debt & $3-4.5 \%$ \\
\hline Subsidized debt limit & $80 \%$ \\
\hline Features & National Provincial and Local \\
\hline $\begin{array}{l}\text { Delay in processing subsidized } \\
\text { debt }\end{array}$ & $<1$ year \\
\hline Facilities grant & $100 \%$ \\
\hline Land grant & $\begin{array}{l}\text { Discount purchase (land use } \\
\text { right) }\end{array}$ \\
\hline Training grant (millions USD) & Yes \\
\hline $\begin{array}{l}\text { Effective corporate income tax } \\
\text { rate }\end{array}$ & $21 \%$ \\
\hline Income tax credits & 20 year holiday \\
\hline Loans/ Loan guarantees & $\begin{array}{l}\text { \$30 billion total credit line from } \\
\text { China development bank. }\end{array}$ \\
\hline
\end{tabular}

Sources: Alan Goodrich, Ted James and Michael Woodhouse, Solar PV manufacturing cost analysis: US competitiveness in a global industry, Stanford University, Precourt institute for energy, 10 Oct 2011.

${ }^{a}$ Chinese Renewables Status Report October 2009, The Renewable Energy Policy Network for the 21st century.

\section{Microanalysis: The case of Suntech Solar PV manufacturing capabilities}

Suntech $^{17}$ was one of the earlyfirms engaged in solar manufacturing and is

Journal of Technology Management for Growing Economies, Volume 3, Number 2, October 2012 
now the leading firms in the world's silicon solar panel manufacturers. The firm started since 2001 and has become global, spreading to 80 countries. Its founder Dr. Shi Zhengrong graduated from Changchun University of science and technology in China in 1983 and received masters in laser physics from Shanghai Institute of optics and fine mechanics in 1986 before entering University of New South Wales in Australia. He believed in research and development and had close cooperation with academia such as University of south wales (Australia) specifically in new generation technologies.

Suntech started production since 2002, and by 2005 it was ranked by Photon International magazine as the world's top 10 PV cell makers in 2004. In 2005, with the support of Wuxi government it was listed in New York stock exchange and later released into a fully-fledged private enterprise. It proved its technology to the nation by winning the contract to supply the solar panels for the revolutionary Bird's Nest of 2008 Olympics which was a 130 Kilo watt solar installation. Suntech technology delivers a $19 \%$ for monocrystalline solar $17 \%$ conversion efficiency and for second generation (polycrystalline PV cells in 2009) it showed 17\% efficiency. In 2011 it crossed the mark of $2 \mathrm{GW}$ annual production capacity.

For example, the Suntech researchers brought in a complicated technology of the 1990s, that depended on sophisticated processes like photolithography and vacuum deposition from the labs of the University of South Wales, Australia, and showed a clever way of incorporating to a production assembly line with reducing cost with improvement of performance of $10 \%$ from the initial 205 watts range. They setup a pilot line in 2009 and faced challenges during production scaling.

A patent search of Suntech shows it has utility and application patents of 291 in China patent office and in outside China it has submitted 1551 patents.

In 2010, the US secretary of state confirmed from his visit to Suntech Power that he observed the automation with advanced high efficiency product technology was a key in its success. Indigenously they have shown indigenous process innovations to reduce silicon consumption, for example Suntech's annual report says the production team has found ways to use thinner silicon wafers to enhance production by reducing the silicon wafer thickness (180 micron range $)^{18}$. The manufacturing processes have been constantly revised to show that their learning process is enhancing. For example, the conductive metal lines that collect electric charge from the silicon aren't created with standard methods like screen-printing process; instead, Suntech uses a proprietary process to deposit much thinner, more closely spaced lines that are more efficient at extracting electricity from the cells. The changes have allowed the firm to reach efficiency levels and cost reductions that an industry road map

Journal of Technology Management for Growing Economies, Volume 3, Number 2, October 2012
Fusing East and West 
Srikanth, N.

Watanabe, C. released in 2011 had set as targets for 2020. As Stuart Wenham the chief technology officer at Suntech puts it, "When you put all those things together, we are not only doing better than what people are doing now, We are also doing better than what they think they could be doing in 10 years." This year Suntech is poised to increase production of the new generation cells, and annually generate 500 megawatts of power-roughly 2.5 million solar panels.

In 2010, when US secretary of Energy Steven Chu gave a speech to the National press club, he pointed out that he was impressed with Suntech manufacturing competence when he toured the factory and found it to be "high-tech automated factory" and mentioned that "it's not succeeding because of cheap labour" and it had developed a type of solar cell with world record efficiencies. This convinces us the state of indigenization of China is internationally good.

\section{CONCLUSION}

In light of a conspicuous strength in solar PV cell and module manufacturing in recent years this study investigated the institutional sources of its strength. Empirical analysis was conducted focusing on the interaction between indigenous semiconductor manufacturing industry and newly emerging solar PV manufacturing industry in absorption of global best practices thereby fusion between them was demonstrated.

Noteworthy findings obtained include:

(i) Success of the fusion can be attributed to a joint work between industry's intensive effort in learning global best practices and existing knowhow for exploring new business,

(ii) Technology contributes significantly to production increase in solar industry and thus an increase in technology stock by assimilation capability,

(iii) A set of 74 leading domestic solar PV manufacturing firms shows the evidence of positive knowledge spillage from the existing semiconductor industry,

(iv) The top 23 leading domestic solar PV manufacturing firms exhibits an assimilation capacity of 0.24 in learning the global best practices from global MNE solar firms,

(v) Improvement of assimilation capacity is essential for effective utilization of spillover technology, and this depends on the level of technology stock and skilled labour in the host,

Journal of Technology Management for Growing Economies, Volume 3, Number 2, October 2012 
(vi) A new way of identifying the technology spillover and competence growth using patent technology class has been demonstrated,

(vii) Government's catalytic role insupporting the solar manufacturing industry has aided the attainment of decarbonisation society for nation's sustainability, and

(viii) The evidence demonstrates the possibility that developing countries can take an alternative path of development with green technology industries growing by its conspicuous strength and leapfrogging into global low carbon economy.

These findings provide important policy implications suggestive to growing economies for their advancement of competitive industries:

(i) From the success of China's solar industry evolution and growth, growing economies such as India can evaluate their own conspicuous strengths based on their technology stock, exports, productivity, etc., as measures and devise roadmaps for possible inception of new industry by exploitingtheir intrinsic know-how.

(ii) The present study showed convincing facts that the global MNEs knowledge spillover to the domestic firms helped to acquire global best practices and thereby reached export quality. Thus growing economies should promote the co-existence of foreign direct invested MNEs with domestic firm evolution to promote knowledge spillover, labour mobility and supply chain evolution.

(iii) It is appealing to find that China even with initial meagre domestic installations has demonstrated its conspicuous strength through enormous production capability to become the world leading manufacturer and exporter of solar PV cells and modules. However,the West (USA and Europe) presently views China's price reduction capability as an act of dumping of the solar PV products below the manufacturing price. If proven, this may affect the China's exports.Secondly, China's energy mix presently shows solar PV sources constitutes not even $1 \%$. Hence it is recommended that China can develop the domestic market to sufficient level such that it meets their growing energy needs, ensure a sustainable growth for its solar PV manufacturing industry, and ensure the country to become a decarbonized region.

(iv) Having understood the technology relevance between any two different industries, growing economies should promote geographic proximity 
Srikanth, N.

Watanabe, C.

in accordance to the technology distance between two industries. This will aid knowledge spillover through labour mobility and easy supply chain formation. For example, the upcoming LED factories and sensor manufacturing industries of China can benefit from similar knowledge spillage of semiconductor industry.

(v) In order to promote more tacit knowledge spillover between industries and their firms, labour mobility should be promoted through incentives. It is risky for employees to move to other industries at elderly age, but if incentivized, they can be carriers of knowledge and induce new innovations and help emerge new industries and create conspicuous strength for the nation.

Similar investigations taking a conspicuous development of China's wind power development advancement is strongly recommended as a next step together with further analysis of learning processes as well as investigate its roots of knowledge sources.

\section{FOOTNOTE}

1. Financial Times - China's Rush Into Renewables: The Way The World Turns (28 November 2011) : http://www.ft.com/intl/cms/s/0/0502a28a15c9-11e1-a691-00144feabdc0.html\#axzz1nmZeqJQF.

2. http://cleantechnica.com/2012/02/12/dumping-solar-study-sheds-lighton-solar-pv-trade-flows-us-China-manufacturing/

3. Reuters (2012), China's solar companies warn of trade war with EU, http://www.reuters.com/article/2012/07/26/us-China-solar-eu-idUSBRE86P14220120726.

4. Solar and Renewable Energy Sources, China Solar Energy, 2010-02, 38, available at http://www. Chinaygny.cn/

5. Kevin Bullis, The Chinese Solar Machine, January/February 2012, http:// www.technologyreview.com/energy/39356/.

6. www.casolarco.com

7. The PV cell price 'c' (Yuan/ Watt) and the cumulative production ' $Q$ ' (MW) in the $\log -\log$ chart was found to be $\mathrm{Q}=64.1 * \mathrm{C}-0.21$ and thus a learning rate of 0.14 (Zhang et al. (2012)).

8. Gordon Brinser, President of SolarWorld Industries America, www.solarworld-usa.com

9. Shyam Mehta, Senior Analyst at GTM Research, www.greentechmedia.

Journal of Technology Management for Growing Economies, Volume 3, Number 2, October 2012 
com/research/.

10. http://www.greentechfocus.com/indexphp\#state=CompanyDetail\& id $=963$.

11. http://www.technologyreview.com/energy/39356/.

12. XinXin Kong (National Research Center for Science and Technology for Development) finds that the China electronic industry production function:Production $(\mathrm{MW})=0.592 *$ Capacity $0.539 *$ Employees 0.422 .

13. http://cleantechnica.com/2012/02/12/dumping-solar-study-sheds-lighton-solar-pv-trade-flows-us-China-manufacturing/.

14. http://www.americansolarmanufacturing.org/news-releases/0207-12-casm-federal-research-lab.htm.

15. http://www.americansolarmanufacturing.org/news-releases/0207-12-casm-federal-research-lab.htm.

16. Chinese Renewables Status Report October 2009, The Renewable Energy Policy Network for the 21st century.

17. Suntech: http://am.suntech-power.com/about.html.

18. KanSichao, Chinese photovoltaic market and industry outlook - part 1, IEEJ, April 2010, pp. 1-12.

\section{REFERENCES}

Anon, A. (1998) 'Analytical report on technology, productivity and job creation - Best policy practices', OECD, Paris, 1998.

Anselin, L., Varga, A., and Zoltan A. (2000) Geographical Spillovers and University Research: A Spatial Econometric Perspective, Growth and Change, Volume 31, Issue 4, pages 501515, Fall 2000.

Arnaud T., Glachant, M., and Meniere, Y. (2011) 'Innovation and international technology transfer: the case of Chinese photovoltaic industry', Energy policy (2011) 761-770. http://dx. doi.org/10.1016/j.enpol.2010.10.050.

Arrow K.J. (1962) 'Economic Welfare and the Allocation of Resources for Innovation', in: The Rate and Direction of Technical Change, R. Nelson, (Ed.), New York, National Bureau of Economic Research, 1962.

Balzat, M., and Hanusch, H. (2004) 'Recent trends in the research on national innovation systems', Journal of evolutionary economics, 14, 2004, pp. 197-210. http://dx.doi.org/10.1007/ s00191-004-0187-y.

Bin, X. (2007) 'Trade, foreign direct investment and productivity of China's private enterprises' in Eds. Shuanglin L., and Xiaodong Z. 'Private enterprises and China's economic development', Routledge, London, 2007, pp. 159-172.

Blake, A., Zileng, D., and Falney, R.(2009) 'How does the productivity of foreign direct investment spill over to local firms in Chinese manufacturing', Journal of Chinese economic and business studies, vol. 7, no.2, May 2009, pp. 183-199.

Branstetter, L.,(1998) 'Looking for International Knowledge Spillovers: A Review of the Literature with Suggestions for New Approaches', Annales d'Economie et de Statistique No.

Journal of Technology Management for Growing Economies, Volume 3, Number 2, October 2012
Fusing East and West 
Srikanth, N.

Watanabe, C.
49/50, 1998, pp. 517-540.

Brinser, G., Hart, M., Mehta, S., Shah, J., andWanless, R. (2012) 'China Solar Industry and the US antidumping - anti subsidy trade case', A Kearny alliance project, ChinaGlobalTrade. com, May 2012.

Chetan, S. Solar photovoltaics: Fundamentals, technologies and applications, PHI publications, New Delhi, 2009.

Fosfuri, A., Motta, M., and Ronde,T.(2001), "Foreign direct investment and spillovers throughworkers' mobility", Journal of International Economics, 53, pp. 205-222. http://dx.doi. org/10.1016/S0022-1996(00)00069-6.

Goodrich, A., Ted J., and Woodhouse, M. (2011)'Solar PV manufacturing cost analysis: UZS competitiveness in a global industries',Stanford university, Oct $10^{\text {th }} 2011$, NREL/PR6A20-53938, pp. 1-45.

Griliches, Z. (1998) 'R\&D and productivity: the econometric evidence', Scandinavian Journal of economics The University of Chicago, IL, 1998, pp. 251-268.

Griffith, R., and Reenan V.(2003)'R\&D and absorptive capacity: Theory and empirical evidence', Scandinavian Journal of Economics, vol. 105:1, 2003, pp. 99-118.

Griffith, R., and Reenan V. (2004)'Mapping the two faces of R\&D: productivity growth in a panel of OECD industries', Review of Economics and Statistics, 86, 883-95.

Grossman G., and Helpman, M.(1991)'Trade, knowledge spillovers and growth', European Economic Review, 35:2-3, 1991, pp. 517-526. http://dx.doi.org/10.3386/w3485.

Hart M. (2011) 'Shining a light on US-China energy cooperation, Center for American Progress', Feb 2011.

Jaffe, A. (1986) 'Technological opportunity and spillovers of R\&D: evidence from firms' patents, profits and market value', 76:5, 1986, pp. 984-1001.

Jaffe, A.,Trajtenberg, M., and Henderson, R. (1993) 'Geographic localization of knowledge spilllovers as evidenced by patent citations', Quarterly Journal of Economics, 108:3, 1993, pp. 577-598.

Kan, S. (2010) 'Chinese photovoltaic market and industry outlook - part 1', IEEJ, April 2010, pp. 1-12.

Keith, B.(2011) ‘Trade war in solar takes shape', New York Times, 11 th Nov. 2011.

Kevin, B.(2012)'The Chinese Solar Machine', Jan. 2012, http://www.technologyreview.com/ energy/39356/

Kinoshita, Y.(2001) ${ }^{\circ}$ R\&D and Technology Spillovers through FDI: Innovation and Absorptive Capacity'. CEPR Discussion Paper no. 2775. London, Centre for Economic Policy Research. http://www.cepr.org/pubs/dps/DP2775.asp.

Liu, X., Parkar, D., Vaidya, K., and Wei, Y. (2001) 'The impact of foreign direct investment on labour productivity in the Chinese electronics industry', International business review, 10 (2001) 421-439. http://dx.doi.org/10.1016/S0969-5931(01)00024-5.

Maskus, K. E. (2004) 'Encouraging Technology Transfer,” report for UNCTAD/ICTSD, Project on Intellectual Property Rights and Sustainable Development', Issue Paper no. 7, 2004.

Mark, N.(2011) 'Economic impact of the photovoltaic industry in China after the financial crisis of 2009', The Chinese economy, 44:3, 2011, pp. 22-44.

Miller, M., and Upadhay, V. (2000) 'The effects of openness, trade orientation, and human capital on total factor productivity', Journal of development economics, 63, pp. 399-423.

Nelson, R. (1959) 'The Simple Economics of Basic Research', Journal of Political Economy, 67, pp. 297-306.

Tilman, A., Schmitz, H., Stamm, A. 'Breakthrough? China's and India's Transition from Production to Innovation', World Development, 36:2, 2008, pp. 325-344. http://dx.doi. org/10.1016/j.worlddev.2007.06.011.

Watanabe, C., Wakabayashi, K., and Miyazawa, T. (2000) 'Industrial dynamism and the creation

Journal of Technology Management for Growing Economies, Volume 3, Number 2, October 2012 
of a virtuous cycle between R\&D, market growth and price reduction', Technovation 20 , no. 6, (2000) pp. 299-312. http://dx.doi.org/10.1016/S0166-4972(99)00146-7.

Watanabe, C., Takayama, M., Nagamatsu, A,Tagami, T., andBrown, C.C. (2002) 'Technology spillover as a complement for high level R\&D intensity in the pharmaceutical industry', Technovation 22 (2002) 245-258.

Wiser, H., and Wingate, M. (2002)'Renewable energy options for China: a comparison of renewable portfolio standards, feed in tariffs, and tendering policies', Center for resource solutions, 2002.

Yang, M., and Pan, R.F. (2010) 'Harvesting sunlight: solar photovoltaic industry in China', East Asian Institute, NUS, 2010.

Yang, M., and Pan, R. (2011) 'Harvesting Sunlight: Solar Photovoltaic Industry in China'. China's Industrial Development In The 21st Century, East Asian Institute, National University of Singapore, 2011, pp. 171-197.

Zhang, D., Chai,Q., Zhang, X., He, J., Yue, L., Dong, X., and Wu, S. (2012) 'Economic assessment of large scale photovoltaic power development in China', Energy, 40 (2012) 370-375. http://dx.doi.org/10.1016/j.energy.2012.01.053.

Zhen,Y.Z., Zhang, S.Y., andZuo, J. (2011) 'A critical analysis of the photovoltaic power industry in China - from diamond model to gear model', Renewable and sustainable energy reviews, 15 (2011) 4673- 4971. http://dx.doi.org/10.1016/j.rser.2011.07.057.

Narasimalu Srikanth, National University of Singapore, Singapore. Email: g0600356@nus.edu.sg.

Chihiro Watanabe, is Professor, Department of Industrial Management Tokyo Seitoku University, Singapore. Email: watanabe.c.pqr@gmail.com.
Fusing East and West 
Srikanth, N.

Watanabe, C.

\section{2}

\section{APPENDIX}

Table A1: List of China solar firms (2011)

\begin{tabular}{|c|c|c|c|c|}
\hline & Registered Name & $\begin{array}{l}\text { Capacity } \\
\text { (in MW) }\end{array}$ & Employees & $\begin{array}{l}\text { Registered } \\
\text { Year }\end{array}$ \\
\hline 1 & Suntech Power Holdings & 2400 & 8000 & 2001 \\
\hline 2 & Yingli Green Energy & 2000 & 6000 & 1998 \\
\hline 3 & JA Solar Holdings, Co., Ltd. & 3000 & 5458 & 2005 \\
\hline 4 & Motech Industries Inc & 2000 & 1386 & 1981 \\
\hline 5 & Trina Solar Limited & 1900 & 4600 & 1997 \\
\hline 7 & $\begin{array}{l}\text { Hanwha SolarOne (formerly Solar- } \\
\text { fun) }\end{array}$ & 1300 & 3989 & 2004 \\
\hline 8 & Neo Solar Power (NSP) & 1300 & 500 & 2009 \\
\hline 9 & E-Ton Solar Tech. Co., Ltd & 700 & 900 & 2001 \\
\hline 10 & China Sunergy Co., Ltd. & 400 & 1800 & 2004 \\
\hline \multirow[t]{2}{*}{11} & $\begin{array}{l}\text { SHENZHEN TOPRAYSOLAR } \\
\text { Co.,Ltd.(TOPRAYSOLAR) }\end{array}$ & 190 & 848 & 2002 \\
\hline & $\begin{array}{l}\text { Eging Technology Co., Ltd. Chang- } \\
\text { zhou }\end{array}$ & 250 & 800 & 2003 \\
\hline 14 & $\begin{array}{l}\text { JETION SOLAR HOLDINGS } \\
\text { LIMITED }\end{array}$ & 250 & 900 & 2007 \\
\hline 15 & Anhui Tianyi Solar Energy Co., LTD & 300 & 700 & 2010 \\
\hline 16 & Zhengrong Solar Company & 170 & 600 & 2010 \\
\hline 17 & Bright solar energy Co, Ltd & 400 & 500 & 2008 \\
\hline 18 & Best Solar Co., LTD & 250 & 800 & 2007 \\
\hline 19 & $\begin{array}{l}\text { BOMEX SOLAR NEW ENERGY } \\
\text { CO.,LTD }\end{array}$ & 150 & 600 & 2008 \\
\hline 20 & Nesl Solar Company & 400 & 900 & 2006 \\
\hline 21 & UE Solar Co.,ltd & 300 & 900 & 2007 \\
\hline 22 & Daqo New Energy Co.,Ltd & 200 & 610 & 2006 \\
\hline 23 & Aode New Energy Co., Ltd & 300 & 1200 & 2007 \\
\hline 24 & Risen Energy Co.,Ltd & 300 & 1000 & 2002 \\
\hline 25 & $\begin{array}{l}\text { Dongguan Quoncion Solar Energy } \\
\text { Co.,Ltd }\end{array}$ & 150 & 1000 & 2003 \\
\hline 26 & $\begin{array}{l}\text { Jiangsu Jiao Sheng Photovoltaic } \\
\text { Technology Co. Ltd }\end{array}$ & 300 & 1300 & 2004 \\
\hline 27 & DongyingFuda Solar Power Co.,Ltd & 200 & 800 & 2007 \\
\hline
\end{tabular}

Journal of Technology Management for Growing Economies, Volume 3, Number 2, October 2012 


\begin{tabular}{|c|c|c|c|c|}
\hline & Registered Name & $\begin{array}{l}\text { Capacity } \\
\text { (in MW) }\end{array}$ & Employees & $\begin{array}{l}\text { Registered } \\
\text { Year }\end{array}$ \\
\hline 28 & Konca Solar (Wuxi) Co., Ltd. & 100 & 1300 & 2005 \\
\hline 29 & $\begin{array}{l}\text { JiangyinHareon Solar Technology } \\
\text { Co., Ltd. }\end{array}$ & 250 & 1500 & 2004 \\
\hline 30 & $\begin{array}{l}\text { Hangzhou Blue Sun Solar Energy } \\
\text { Technology Co.,Ltd }\end{array}$ & 600 & 1500 & 2007 \\
\hline 31 & Chinaland Solar Company & 200 & 1000 & 2007 \\
\hline 32 & $\begin{array}{l}\text { Hebei JG Solar Energy Technology } \\
\text { Co., Ltd. }\end{array}$ & 200 & 1000 & 2007 \\
\hline 33 & $\begin{array}{l}\text { Huayu electro-optic science and } \\
\text { technology Limited }\end{array}$ & 200 & 800 & 2009 \\
\hline 34 & GrandPower Solar INC & 300 & 1500 & 2010 \\
\hline 35 & Hengji PV-Tech Energy Co.,ltd & 250 & 1500 & 2007 \\
\hline 36 & Jiawei Solar China Co.,Ltd & 500 & 800 & 1993 \\
\hline 37 & WinSun New Energy Co.,Ltd & 350 & 1500 & 2008 \\
\hline 38 & Jiangsu Runda PV Co., Ltd. & 200 & 1000 & 2009 \\
\hline 39 & $\begin{array}{l}\text { Jiangsu Runner PV Technology Co., } \\
\text { Ltd }\end{array}$ & 300 & 1500 & 2009 \\
\hline 40 & $\begin{array}{l}\text { Eoplly New Energy Technology } \\
\text { Co.,Ltd }\end{array}$ & 300 & 1500 & 2006 \\
\hline 41 & Sun Earth Solar Co.,Ltd & 420 & 2000 & 1999 \\
\hline 42 & Realforce Power Co., Ltd & 1250 & 1000 & 1999 \\
\hline 43 & $\begin{array}{l}\text { Shandong Sunneeg Solar Power Co. } \\
\text { Ltd }\end{array}$ & 1100 & 900 & 2008 \\
\hline 44 & $\begin{array}{l}\text { Shandong Thai haidai photovoltaic } \\
\text { technology Co., LTD }\end{array}$ & 200 & 700 & 1999 \\
\hline 45 & Shanxi Rishengda Solar Company & 500 & 800 & 1999 \\
\hline 46 & Shanghai Alex Solar Industry & 400 & 500 & 2007 \\
\hline 47 & $\begin{array}{l}\text { SHANGHAI PUBSOLAR CO., } \\
\text { LTD }\end{array}$ & 150 & 1000 & 2005 \\
\hline 48 & Foxconn Technology Group & 150 & 50000 & 1974 \\
\hline 49 & $\begin{array}{l}\text { Shanghai Prairiesun Solar Technol- } \\
\text { ogy Co., Ltd }\end{array}$ & 700 & 350 & 2009 \\
\hline 50 & $\begin{array}{l}\text { Winchance Solar (Fujian) Technol- } \\
\text { ogy Co., Ltd }\end{array}$ & 300 & 700 & 2007 \\
\hline 51 & $\begin{array}{l}\text { Wuhu MingyuanNewEnergy Tech- } \\
\text { nology Co., Ltd }\end{array}$ & 200 & 700 & 2005 \\
\hline
\end{tabular}

Fusing East and West 
Srikanth, N.

Watanabe, C.

\begin{tabular}{|c|c|c|c|c|}
\hline & Registered Name & $\begin{array}{l}\text { Capacity } \\
\text { (in MW) }\end{array}$ & Employees & $\begin{array}{l}\text { Registered } \\
\text { Year }\end{array}$ \\
\hline 52 & Jolar Technology Corporation & 280 & 1000 & 2008 \\
\hline 53 & Upsolar Co. Ltd & 300 & 1000 & 2006 \\
\hline 54 & Yunnan Tianda Photovoltaic Co., Ltd & 400 & 1000 & 1975 \\
\hline 55 & $\begin{array}{l}\text { Perfect Energy Technology Exhibi- } \\
\text { tion (Shanghai) Co., Ltd }\end{array}$ & 400 & 1300 & 1994 \\
\hline 56 & Perlight Solar Co., Ltd & 200 & 1300 & 2006 \\
\hline 57 & $\begin{array}{l}\text { Zhejiang BLD Solar Technology } \\
\text { Co.,LTD }\end{array}$ & 150 & 800 & 2008 \\
\hline 58 & ZheJiangBeyondsun PV Co., Ltd & 250 & 900 & 2009 \\
\hline 59 & CN Solar Technology Co., LTD & 215 & 700 & 2007 \\
\hline 60 & $\begin{array}{l}\text { Zhejiang Guangyi Optical Energy } \\
\text { Technologies Co., Ltd }\end{array}$ & 250 & 700 & 2007 \\
\hline 61 & $\begin{array}{l}\text { Zhejiang Hengsheng Photovoltaic } \\
\text { Technology Co., Ltd }\end{array}$ & 250 & 1000 & 2007 \\
\hline 62 & $\begin{array}{l}\text { Zhejiang Topoint Photovoltaic } \\
\text { Co.,Ltd. }\end{array}$ & 300 & 2000 & 2007 \\
\hline 63 & Leye Photovoltaic Co.,Ltd & 200 & 1000 & 2009 \\
\hline 64 & $\begin{array}{l}\text { Zhejiang Riyuewang Solar Technol- } \\
\text { ogy Co., Ltd. }\end{array}$ & 150 & 600 & 2004 \\
\hline 65 & $\begin{array}{l}\text { ZHEJIANG RDM TECHNOLOGY } \\
\text { CO.,LTD }\end{array}$ & 120 & 600 & 2010 \\
\hline 66 & Longbai Group Zhejiang Co., Ltd & 100 & 700 & 2007 \\
\hline 67 & $\begin{array}{l}\text { Zhejiang ShinewPhotoelectronic } \\
\text { Technology Co.,Ltd. }\end{array}$ & 200 & 900 & 2008 \\
\hline 68 & $\begin{array}{l}\text { ZG-Cells Group (Hong Kong) } \\
\text { Limited }\end{array}$ & 400 & 900 & 2008 \\
\hline 69 & Zhejiang Aurora PV Solar Co., Ltd & 200 & 900 & 2008 \\
\hline 70 & The 48th Research Institute & 1000 & 1000 & 1964 \\
\hline 71 & $\begin{array}{l}\text { CNPV Dongying Solar Power Co., } \\
\text { Ltd }\end{array}$ & 600 & 1000 & 2006 \\
\hline 72 & $\begin{array}{l}\text { Zhongheng Technology (Tangshan) } \\
\text { Caofeidian Co., Ltd }\end{array}$ & 150 & 1000 & 2009 \\
\hline 73 & Chinalight Solar Co. Ltd & 200 & 400 & 2005 \\
\hline 74 & ET Solar Group & 250 & 3000 & 2007 \\
\hline
\end{tabular}

Journal of Technology Management for Growing Economies, Volume 3, Number 2, October 2012 
Table A2: List of Foreign solar firms (2011)

\begin{tabular}{|c|l|c|c|c|}
\hline Firm & \multicolumn{1}{|c|}{ Registered Name } & Employees & $\begin{array}{c}\text { Capacity } \\
\text { (in MW) }\end{array}$ & $\begin{array}{c}\text { Registered } \\
\text { Year }\end{array}$ \\
\hline 1 & First Solar, Inc. & 4700 & 4000 & 1999 \\
\hline 2 & $\begin{array}{l}\text { Q-Cells Associate Com- } \\
\text { panies }\end{array}$ & 2750 & 150 & 1999 \\
\hline 3 & Sharp Corporation & 54000 & 1100 & 1963 \\
\hline 4 & $\begin{array}{l}\text { KYOCERA Solar, part of } \\
\text { KYOCERA Corporation. }\end{array}$ & 66,496 & 1000 & 1996 \\
\hline 5 & SunPower Corporation. & 5400 & 1300 & 1985 \\
\hline 6 & Sanyo solar & 230 & 1000 & 1975 \\
\hline 7 & REC Solar & 3400 & 400 & 1996 \\
\hline 8 & SolarWorld AG & 2000 & 1250 & 1998 \\
\hline 9 & Isofoton & 800 & 550 & 1981 \\
\hline
\end{tabular}

Source: QResearch (2012).

Table A3: Major PV companies' knowledge sources in China (2007)

\begin{tabular}{|l|c|c|c|l|}
\hline \multicolumn{1}{|c|}{ Firm Name } & $\begin{array}{c}\text { Wafer } \\
\text { and Ingot }\end{array}$ & $\begin{array}{c}\text { PV module } \\
\text { cell/module }\end{array}$ & $\begin{array}{c}\text { PV } \\
\text { system } \\
\text { assembly }\end{array}$ & \multicolumn{1}{|c|}{ Notes on collaboration } \\
\hline $\begin{array}{l}\text { Beijing Corona Technology } \\
\text { Company ltd. }\end{array}$ & & $\begin{array}{l}\text { Yes } \\
\text { academy of sciences }\end{array}$ \\
\hline $\begin{array}{l}\text { Beijing new energy Technology } \\
\text { Development Co. }\end{array}$ & & Yes & $\begin{array}{l}\text { Yontrolled by the Energy } \\
\text { Research Institute, National } \\
\text { development and Reform } \\
\text { Commision }\end{array}$ \\
\hline $\begin{array}{l}\text { Soltech Corp } \\
\text { Techijing YiweiFengla Electronic }\end{array}$ & Yes & Yes & $\begin{array}{l}\text { A chinese US Taiwan joint } \\
\text { venture }\end{array}$ \\
\hline HebeiJinglong Group & Yes & Yes & Yes & Working with Yingli \\
\hline $\begin{array}{l}\text { Baoding TianweiYingli New Energy } \\
\text { Resources co. }\end{array}$ & Yes & Yes & $\begin{array}{l}\text { A HebeiJinglong group } \\
\text { member }\end{array}$ \\
\hline $\begin{array}{l}\text { HebeiNingjinSonggong } \\
\text { Semiconductor Co. }\end{array}$ & & $\begin{array}{l}\text { A pilot enterprise approved } \\
\text { by the state development } \\
\text { planning commisisionto } \\
\text { siliccon PV cells. }\end{array}$ \\
\hline
\end{tabular}


Srikanth, N.

Watanabe, C.

\begin{tabular}{|c|c|c|c|c|}
\hline Firm Name & $\begin{array}{c}\text { Wafer } \\
\text { and Ingot }\end{array}$ & $\begin{array}{l}\text { PV module } \\
\text { cell } / \text { module }\end{array}$ & $\begin{array}{c}\text { PV } \\
\text { system } \\
\text { assembly }\end{array}$ & Notes on collaboration \\
\hline Jinzhou Xinri Silicon Materials Co. & Yes & & & $\begin{array}{l}\text { Working with Monosilicon/ } \\
\text { ingot }\end{array}$ \\
\hline JA solar Co. & & Yes & & JA Solar \\
\hline LDK Solar Energy High-Tech co. & Yes & & Yes & \\
\hline Jingxing Electronic Material & Yes & & & $\begin{array}{l}\text { A HebeiJinglong group } \\
\text { member }\end{array}$ \\
\hline $\begin{array}{l}\text { Linuo PV High Tech Co. } \\
\text { (Shandong) }\end{array}$ & & Yes & & \\
\hline Suntech Power Co. & & Yes & Yes & Working with Suntech \\
\hline $\begin{array}{l}\text { Trina Solar Energy Co. } \\
\text { (Changzhou) }\end{array}$ & & Yes & & \\
\hline Nanjing China Power PV Ltd. & & Yes & & \\
\hline Solarfun Co. (Jiangsu) & & Yes & & Working with Solarfun \\
\hline $\begin{array}{l}\text { Shanghai Solar Energy Science and } \\
\text { Tec }\end{array}$ & & Yes & & \\
\hline $\begin{array}{l}\text { Shanghai Chaori Energy Science } \\
\text { and Technology Co. }\end{array}$ & & Yes & & \\
\hline $\begin{array}{l}\text { Shanghai Linyang Solar energy } \\
\text { Science and Technology Co. }\end{array}$ & & Yes & & Working with Solarfun \\
\hline ZhengjiangRenesola Co. & Yes & & & Renesolar Ltd. \\
\hline Ningbo Solar electric Power Co. & & Yes & & \\
\hline Shenzhen topray Solar Co. & & Yes & & $\begin{array}{l}\text { Products include solar water } \\
\text { heaters as well. }\end{array}$ \\
\hline $\begin{array}{l}\text { Shenzhen Chuangyi Science and } \\
\text { Technology Development co. }\end{array}$ & & Yes & & $\begin{array}{l}\text { Thin film non-silicon cells, } \\
\text { BIPV }\end{array}$ \\
\hline Shenzhen Jiawei Industries Co. & & Yes & & $\begin{array}{l}\text { Products include solar lamps } \\
\text { as well. }\end{array}$ \\
\hline YunanTianda Photovoltaic Co. & & Yes & & \\
\hline China Xinjiang SunOasis Co. & & Yes & Yes & $\begin{array}{l}\text { Cooperating with Tsing Hua } \\
\text { University }\end{array}$ \\
\hline
\end{tabular}

Source: The Renewable Energy Industry Development Report 2008. 
Table A4: List of electronics industries in China (2005)

Fusing East and West

\begin{tabular}{|c|c|c|c|c|}
\hline Category & $\mathbf{K f} / \mathbf{K}^{\mathbf{a}}$ & $\mathbf{K} / \mathbf{L}^{\mathbf{b}}$ & $\mathbf{K} / \mathbf{Y}^{\mathbf{c}}$ & $\begin{array}{c}\text { Revenue/ } \\
\text { Firm }^{\mathrm{d}} \\
\text { (RMB 10K) }^{\text {RMB }}\end{array}$ \\
\hline Complete Radar manufacture & 1.2311 & 1.9147 & 0.3122 & 59177 \\
\hline Special equipment and parts for Radar & 1.7437 & 0.8224 & 1.5431 & 2321 \\
\hline $\begin{array}{l}\text { Wireless transmission equipment } \\
\text { manufacture }\end{array}$ & 21.8544 & 5.1273 & 2.1657 & 30878 \\
\hline Exchange equipment manufacture & 30.4337 & 8.4946 & 0.8575 & 24173 \\
\hline $\begin{array}{l}\text { Wire communication terminal equip- } \\
\text { ment }\end{array}$ & 38.1237 & 3.113 & 1.1884 & 5812 \\
\hline $\begin{array}{l}\text { wireless communication terminal } \\
\text { equipment }\end{array}$ & 32.8871 & 5.9971 & 0.2986 & 54825 \\
\hline Other communicable equipment & 16.2522 & 3.6114 & 1.4 & 6457 \\
\hline $\begin{array}{l}\text { Broadcast and TV equipment manu- } \\
\text { facture }\end{array}$ & 2.9027 & 2.3128 & 2.5941 & 1705 \\
\hline TV set manufacture & 28.4263 & 5.249 & 1.1604 & 30985 \\
\hline Radio and recorder manufacture & 36.7231 & 2.9793 & 1.2106 & 10011 \\
\hline Video manufacture & 47.223 & 17.3272 & 2.6633 & 42123 \\
\hline Other Broadcast equipment & 21.777 & 4.1677 & 2.5588 & 2030 \\
\hline Complete computer manufacture & 15.1064 & 5.0432 & 0.9118 & 24025 \\
\hline $\begin{array}{l}\text { Computer exterior equipment manu- } \\
\text { facture }\end{array}$ & 46.144 & 5.7214 & 0.9432 & 21388 \\
\hline $\begin{array}{l}\text { Computer necessary accessories } \\
\text { manufacture }\end{array}$ & 16.1847 & 5.5873 & 1.0484 & 4654 \\
\hline Software manufacture & 15.3015 & 7.5641 & 0.7766 & 5254 \\
\hline Calculator manufacture & 45.7108 & 2.0051 & 1.2017 & 15477 \\
\hline Other computer accessories & 69.5599 & 10.2727 & 2.1352 & 10099 \\
\hline Electronic micro-electrical machine & 29.059 & 2.8293 & 2.668 & 3635 \\
\hline $\begin{array}{l}\text { Electronic electrical wire and cable } \\
\text { manufacture }\end{array}$ & 12.0793 & 4.0294 & 0.9969 & 8008 \\
\hline Electronic storage battery & 20.7358 & 1.6611 & 1.6275 & 5480 \\
\hline Electronic dry battery & 78.8808 & 9.3314 & 1.5183 & 9131 \\
\hline Electronic component manufacture & 29.4864 & 2.7553 & 1.3959 & 2821 \\
\hline Electronic component special material & 39.4012 & 4.0928 & 2.5573 & 1872 \\
\hline Other electronic components & 33.3621 & 2.1594 & 1.2209 & 1998 \\
\hline
\end{tabular}


Srikanth, N.

Watanabe, C.

\begin{tabular}{|c|c|c|c|c|}
\hline Category & $\mathbf{K f} / \mathbf{K}^{\mathbf{a}}$ & $\mathbf{K} / \mathbf{L}^{\mathbf{b}}$ & $\mathbf{K} / \mathbf{Y}^{\mathbf{c}}$ & $\begin{array}{c}\text { Revenue/ } \\
\text { Firm }^{\mathrm{d}} \\
\text { (RMB 10K) }\end{array}$ \\
\hline $\begin{array}{l}\text { Electronic measuring instrument } \\
\text { manufacture }\end{array}$ & 6.0632 & 2.41 & 1.9358 & 1246 \\
\hline $\begin{array}{l}\text { Others electronic measuring equip- } \\
\text { ment accessories }\end{array}$ & 23.0276 & 3.2736 & 1.4003 & 1848 \\
\hline $\begin{array}{l}\text { Electronic special equipment manu- } \\
\text { facture }\end{array}$ & 29.7506 & 2.6823 & 1.9611 & 2160 \\
\hline $\begin{array}{l}\text { Electronic industrial mould and gear } \\
\text { manufacture }\end{array}$ & 24.1003 & 2.1395 & 2.1287 & 470 \\
\hline $\begin{array}{l}\text { Others electronics special equipment } \\
\text { accessories }\end{array}$ & 19.352 & 2.4677 & 1.0885 & 2232 \\
\hline Refrigerator manufacture & 24.9129 & 8.2622 & 1.7204 & 42421 \\
\hline Electric heating equipment & 64.6789 & 3.9024 & 2.0183 & 8964 \\
\hline Electronic toy manufacture & 28.8084 & 1.3434 & 1.5915 & 1669 \\
\hline Other household electronic appliance & 42.9226 & 6.3778 & 1.3706 & 12547 \\
\hline Other household accessories & 35.7514 & 3.739 & 1.5036 & 1692 \\
\hline Bulb manufacture & 42.4407 & 4.0576 & 1.5461 & 2215 \\
\hline $\begin{array}{l}\text { Electrical vacuum valve device manu- } \\
\text { facture }\end{array}$ & 33.0177 & 9.7229 & 1.8327 & 39140 \\
\hline Semiconductor device manufacture & 30.4874 & 2.3629 & 2.0408 & 1447 \\
\hline Integrated circuit manufacture & 42.9847 & 11.1162 & 3.182 & 8984 \\
\hline $\begin{array}{l}\text { Electronic device material manufac- } \\
\text { ture }\end{array}$ & 34.8098 & 5.7394 & 1.5287 & 6042 \\
\hline Other electronic device accessories & 50.9389 & 8.3568 & 1.9293 & 7197 \\
\hline
\end{tabular}

Source: Yingqi Wei, Xiaming Liu, Page 97, Foreign direct investment in China, Edward Elgar, USA, 2001

${ }^{a} \mathrm{Kf} / \mathrm{K}$ is the share of foreign capital (\%), ${ }^{b} \mathrm{~K} / \mathrm{L}$ is the capital to labour ratio, ${ }^{c} \mathrm{~K} / \mathrm{Y}$ is the capital to output ratio, ${ }^{d}$ firm size is measured by the industrial sales revenue (RMB 10000) divided by the number of firms in each sub-sector. 
Table A5: Dominant technologies Common to both global Semiconductor \& Solar industries' patents (2012)
Fusing East and West

\begin{tabular}{|c|c|c|c|c|}
\hline \multirow[b]{2}{*}{$\begin{array}{l}\text { Technology } \\
\text { (IPC code) }\end{array}$} & \multicolumn{2}{|c|}{ Semiconductor Industry } & \multicolumn{2}{|c|}{ Solar Industry } \\
\hline & $\begin{array}{l}\text { Patent } \\
\text { count }\end{array}$ & $\begin{array}{l}\text { Patent share } \\
\text { (out of top } 100 \\
\text { technologies) }\end{array}$ & $\begin{array}{l}\text { Patent } \\
\text { Count }\end{array}$ & $\begin{array}{l}\text { Patent share (out } \\
\text { of top } 100 \text { technol- } \\
\text { ogies) }\end{array}$ \\
\hline $\mathrm{A} 01 \mathrm{~N}$ & 638 & $0.59 \%$ & 169 & $0.23 \%$ \\
\hline A61B & 506 & $0.47 \%$ & 172 & $0.24 \%$ \\
\hline A61F & 495 & $0.46 \%$ & 188 & $0.26 \%$ \\
\hline A61K & 5412 & $5.04 \%$ & 2364 & $3.26 \%$ \\
\hline A61L & 496 & $0.46 \%$ & 177 & $0.24 \%$ \\
\hline $\mathrm{A} 61 \mathrm{~N}$ & 167 & $0.16 \%$ & 99 & $0.14 \%$ \\
\hline A61P & 1399 & $1.30 \%$ & 1174 & $1.62 \%$ \\
\hline A61Q & 656 & $0.61 \%$ & 702 & $0.97 \%$ \\
\hline B01D & 895 & $0.83 \%$ & 385 & $0.53 \%$ \\
\hline B01J & 3038 & $2.83 \%$ & 998 & $1.38 \%$ \\
\hline B05D & 714 & $0.66 \%$ & 933 & $1.29 \%$ \\
\hline $\mathrm{B} 22 \mathrm{~F}$ & 289 & $0.27 \%$ & 183 & $0.25 \%$ \\
\hline $\mathrm{B} 23 \mathrm{~K}$ & 513 & $0.48 \%$ & 258 & $0.36 \%$ \\
\hline B24B & 312 & $0.29 \%$ & 80 & $0.11 \%$ \\
\hline B24D & 267 & $0.25 \%$ & 82 & $0.11 \%$ \\
\hline B29C & 801 & $0.75 \%$ & 471 & $0.65 \%$ \\
\hline B29D & 181 & $0.17 \%$ & 87 & $0.12 \%$ \\
\hline B32B & 2048 & $1.91 \%$ & 2593 & $3.58 \%$ \\
\hline B41J & 686 & $0.64 \%$ & 92 & $0.13 \%$ \\
\hline B41M & 396 & $0.37 \%$ & 140 & $0.19 \%$ \\
\hline B65D & 229 & $0.21 \%$ & 97 & $0.13 \%$ \\
\hline B81C & 331 & $0.31 \%$ & 87 & $0.12 \%$ \\
\hline B82B & 212 & $0.20 \%$ & 556 & $0.77 \%$ \\
\hline C01B & 1615 & $1.50 \%$ & 1610 & $2.22 \%$ \\
\hline $\mathrm{C} 01 \mathrm{~F}$ & 207 & $0.19 \%$ & 122 & $0.17 \%$ \\
\hline $\mathrm{C} 01 \mathrm{G}$ & 465 & $0.43 \%$ & 681 & $0.94 \%$ \\
\hline $\mathrm{C} 02 \mathrm{~F}$ & 135 & $0.13 \%$ & 234 & $0.32 \%$ \\
\hline $\mathrm{C} 03 \mathrm{~B}$ & 256 & $0.24 \%$ & 130 & $0.18 \%$ \\
\hline
\end{tabular}


Srikanth, N.

Watanabe, C.

\begin{tabular}{|c|c|c|c|c|}
\hline \multirow[b]{2}{*}{$\begin{array}{l}\text { Technology } \\
\text { (IPC code) }\end{array}$} & \multicolumn{2}{|c|}{ Semiconductor Industry } & \multicolumn{2}{|c|}{ Solar Industry } \\
\hline & $\begin{array}{l}\text { Patent } \\
\text { count }\end{array}$ & $\begin{array}{l}\text { Patent share } \\
\text { (out of top } 100 \\
\text { technologies) }\end{array}$ & $\begin{array}{l}\text { Patent } \\
\text { Count }\end{array}$ & $\begin{array}{c}\text { Patent share (out } \\
\text { of top } 100 \text { technol- } \\
\text { ogies) }\end{array}$ \\
\hline $\mathrm{C} 03 \mathrm{C}$ & 844 & $0.79 \%$ & 893 & $1.23 \%$ \\
\hline C04B & 1425 & $1.33 \%$ & 453 & $0.62 \%$ \\
\hline $\mathrm{C} 07 \mathrm{C}$ & 2885 & $2.69 \%$ & 753 & $1.04 \%$ \\
\hline C07D & 4310 & $4.01 \%$ & 1529 & $2.11 \%$ \\
\hline $\mathrm{C} 07 \mathrm{~F}$ & 1270 & $1.18 \%$ & 562 & $0.78 \%$ \\
\hline $\mathrm{C} 07 \mathrm{H}$ & 562 & $0.52 \%$ & 151 & $0.21 \%$ \\
\hline $\mathrm{C} 07 \mathrm{~K}$ & 629 & $0.59 \%$ & 256 & $0.35 \%$ \\
\hline $\mathrm{C} 08 \mathrm{~F}$ & 2322 & $2.16 \%$ & 698 & $0.96 \%$ \\
\hline $\mathrm{C} 08 \mathrm{G}$ & 1408 & $1.31 \%$ & 1052 & $1.45 \%$ \\
\hline C08J & 1022 & $0.95 \%$ & 844 & $1.16 \%$ \\
\hline $\mathrm{C} 08 \mathrm{~K}$ & 1318 & $1.23 \%$ & 1355 & $1.87 \%$ \\
\hline $\mathrm{C} 08 \mathrm{~L}$ & 2288 & $2.13 \%$ & 1820 & $2.51 \%$ \\
\hline $\mathrm{C} 09 \mathrm{~B}$ & 210 & $0.20 \%$ & 373 & $0.51 \%$ \\
\hline $\mathrm{C} 09 \mathrm{C}$ & 299 & $0.28 \%$ & 179 & $0.25 \%$ \\
\hline C09D & 793 & $0.74 \%$ & 817 & $1.13 \%$ \\
\hline C09J & 274 & $0.26 \%$ & 366 & $0.50 \%$ \\
\hline $\mathrm{C} 09 \mathrm{~K}$ & 1651 & $1.54 \%$ & 1797 & $2.48 \%$ \\
\hline C11D & 670 & $0.62 \%$ & 130 & $0.18 \%$ \\
\hline $\mathrm{C} 12 \mathrm{~N}$ & 780 & $0.73 \%$ & 268 & $0.37 \%$ \\
\hline $\mathrm{C} 12 \mathrm{P}$ & 216 & $0.20 \%$ & 136 & $0.19 \%$ \\
\hline C12Q & 637 & $0.59 \%$ & 145 & $0.20 \%$ \\
\hline $\mathrm{C} 22 \mathrm{C}$ & 547 & $0.51 \%$ & 198 & $0.27 \%$ \\
\hline $\mathrm{C} 23 \mathrm{C}$ & 2557 & $2.38 \%$ & 2768 & $3.82 \%$ \\
\hline $\mathrm{C} 23 \mathrm{~F}$ & 193 & $0.18 \%$ & 117 & $0.16 \%$ \\
\hline C25D & 157 & $0.15 \%$ & 206 & $0.28 \%$ \\
\hline C30B & 2088 & $1.94 \%$ & 2008 & $2.77 \%$ \\
\hline D01F & 330 & $0.31 \%$ & 194 & $0.27 \%$ \\
\hline E21B & 277 & $0.26 \%$ & 426 & $0.59 \%$ \\
\hline G01J & 405 & $0.38 \%$ & 177 & $0.24 \%$ \\
\hline G01N & 2005 & $1.87 \%$ & 543 & $0.75 \%$ \\
\hline G01R & 486 & $0.45 \%$ & 157 & $0.22 \%$ \\
\hline
\end{tabular}

Journal of Technology Management for Growing Economies, Volume 3, Number 2, October 2012 


\begin{tabular}{|c|c|c|c|c|}
\hline \multirow[b]{2}{*}{$\begin{array}{l}\text { Technology } \\
\text { (IPC code) }\end{array}$} & \multicolumn{2}{|c|}{ Semiconductor Industry } & \multicolumn{2}{|c|}{ Solar Industry } \\
\hline & $\begin{array}{c}\text { Patent } \\
\text { count }\end{array}$ & $\begin{array}{c}\text { Patent share } \\
\text { (out of top } 100 \\
\text { technologies) }\end{array}$ & $\begin{array}{l}\text { Patent } \\
\text { Count }\end{array}$ & $\begin{array}{l}\text { Patent share (out } \\
\text { of top } 100 \text { technol- } \\
\text { ogies) }\end{array}$ \\
\hline G02B & 2496 & $2.32 \%$ & 1407 & $1.94 \%$ \\
\hline $\mathrm{G} 02 \mathrm{~F}$ & 2971 & $2.77 \%$ & 1373 & $1.89 \%$ \\
\hline G03C & 680 & $0.63 \%$ & 112 & $0.15 \%$ \\
\hline G03F & 1033 & $0.96 \%$ & 210 & $0.29 \%$ \\
\hline G03G & 1298 & $1.21 \%$ & 322 & $0.44 \%$ \\
\hline G06F & 428 & $0.40 \%$ & 247 & $0.34 \%$ \\
\hline G06K & 261 & $0.24 \%$ & 178 & $0.25 \%$ \\
\hline G09F & 384 & $0.36 \%$ & 223 & $0.31 \%$ \\
\hline G09G & 1030 & $0.96 \%$ & 229 & $0.32 \%$ \\
\hline G11B & 1555 & $1.45 \%$ & 305 & $0.42 \%$ \\
\hline G11C & 1705 & $1.59 \%$ & 224 & $0.31 \%$ \\
\hline H01B & 548 & $0.51 \%$ & 1405 & $1.94 \%$ \\
\hline $\mathrm{H} 01 \mathrm{G}$ & 284 & $0.26 \%$ & 691 & $0.95 \%$ \\
\hline H01J & 1482 & $1.38 \%$ & 548 & $0.76 \%$ \\
\hline H01L & 22732 & $21.16 \%$ & 21627 & $29.84 \%$ \\
\hline $\mathrm{H} 01 \mathrm{M}$ & 861 & $0.80 \%$ & 1867 & $2.58 \%$ \\
\hline H01S & 921 & $0.86 \%$ & 449 & $0.62 \%$ \\
\hline $\mathrm{H} 02 \mathrm{~N}$ & 212 & $0.20 \%$ & 360 & $0.50 \%$ \\
\hline $\mathrm{H} 04 \mathrm{~N}$ & 502 & $0.47 \%$ & 110 & $0.15 \%$ \\
\hline H05B & 782 & $0.73 \%$ & 750 & $1.03 \%$ \\
\hline $\mathrm{H} 05 \mathrm{~K}$ & 678 & $0.63 \%$ & 390 & $0.54 \%$ \\
\hline
\end{tabular}

Fusing East and West

Source: Computed from Thomson Database (2012) 
Srikanth, N. Watanabe, C.
Table A6: Cronology of significant PV policies in China

\begin{tabular}{|c|c|c|c|}
\hline Year & Organization & Policy & Key Points \\
\hline 2005 & Renewable energy law & Renewable energy law & $\begin{array}{l}\text { The NPC passed the law in } 2005 \\
\text { for its implementation in } 2006 \text {. }\end{array}$ \\
\hline 2005 & $\begin{array}{l}\text { National Development } \\
\text { and Reform Commision }\end{array}$ & $\begin{array}{l}\text { Renewable energy } \\
\text { industry development } \\
\text { instruction list }\end{array}$ & $\begin{array}{l}\text { The list spells out } 88 \text { renewable } \\
\text { energy areas including } 35 \mathrm{PV} \\
\text { areas subject to support. }\end{array}$ \\
\hline 2006 & $\begin{array}{l}\text { National Development } \\
\text { and Reform Commision }\end{array}$ & $\begin{array}{l}\text { Provisional administra- } \\
\text { tive measures on pricing } \\
\text { and cost sharing for } \\
\text { renewable energy power } \\
\text { generation. }\end{array}$ & $\begin{array}{l}\text { The document covers how to } \\
\text { calculate feed in tariff for renew- } \\
\text { able energy and the feed in tariff } \\
\text { system. }\end{array}$ \\
\hline 2006 & $\begin{array}{l}\text { National Development } \\
\text { and Reform Commision }\end{array}$ & $\begin{array}{l}\text { Adminstrative } \\
\text { provisions for } \\
\text { renewable energy power } \\
\text { generation. }\end{array}$ & $\begin{array}{l}\text { The document specifies the scope } \\
\text { of management responsibility for } \\
\text { the central and local goverments, } \\
\text { the scope of responsibility for cen } \\
\text { tral government organizations, and } \\
\text { the responsibilities and obligations } \\
\text { of electric power generation and } \\
\text { transmission companies. }\end{array}$ \\
\hline 2006 & Ministry of finance & $\begin{array}{l}\text { Provisional } \\
\text { administrative measures } \\
\text { on the renewable energy } \\
\text { development fund. }\end{array}$ & $\begin{array}{l}\text { the document specifies the scope } \\
\text { for support from the Renewable } \\
\text { energy development fund and } \\
\text { explains the procedures for } \\
\text { applications for financial support } \\
\text { and their acceptance. It also } \\
\text { clarifies financial support methods } \\
\text { and the scope of their applications } \\
\text { and specifies the responsibility for } \\
\text { monitoring and reporting uses of } \\
\text { the fund. }\end{array}$ \\
\hline 2006 & $\begin{array}{l}\text { Ministry of finance and } \\
\text { ministry of construction }\end{array}$ & $\begin{array}{l}\text { Provisional } \\
\text { adminstrative measures } \\
\text { on the fund for } \\
\text { renewable energy } \\
\text { applications for } \\
\text { buildings. }\end{array}$ & $\begin{array}{l}\text { The document specifies how local } \\
\text { government regulatory organiza- } \\
\text { tions should consider applications } \\
\text { for subsidies for projects to use } \\
\text { renewable energy in buildings and } \\
\text { how they should appropriate those } \\
\text { subsidies. }\end{array}$ \\
\hline 2006 & $\begin{array}{l}\text { Ministry of finance and } \\
\text { ministry of construction }\end{array}$ & $\begin{array}{l}\text { Instructions on delib- } \\
\text { eration process of pilot } \\
\text { projects for renewable } \\
\text { energy applications for } \\
\text { buildings }\end{array}$ & $\begin{array}{l}\text { The document specifies how } \\
\text { local government regulatory } \\
\text { organizations should deliberate } \\
\text { pilot projects. Approved projects } \\
\text { will announced annually. }\end{array}$ \\
\hline 2007 & $\begin{array}{l}\text { Ministry of science and } \\
\text { technology, national de- } \\
\text { velopment and reform } \\
\text { commision. }\end{array}$ & $\begin{array}{l}\text { Renewable energy and } \\
\text { new energy international } \\
\text { cooperation plan. }\end{array}$ & $\begin{array}{l}\text { The plan promotes international } \\
\text { cooperation in research on } \\
\text { renewable energy and new energy } \\
\text { priorities. }\end{array}$ \\
\hline
\end{tabular}




\begin{tabular}{|c|c|c|c|}
\hline Year & Organization & Policy & Key Points \\
\hline 2007 & $\begin{array}{l}\text { National Development } \\
\text { and Reform Commision }\end{array}$ & $\begin{array}{l}\text { Temporary measures of } \\
\text { regulation on renewable } \\
\text { energy surcharge. }\end{array}$ & $\begin{array}{l}\text { The document provides for how } \\
\text { electric power transmission } \\
\text { companies should collect and use } \\
\text { renewable energy surcharges. }\end{array}$ \\
\hline 2007 & $\begin{array}{l}\text { National Development } \\
\text { and Reform Commision }\end{array}$ & $\begin{array}{l}\text { Medium to long term } \\
\text { renewable energy devel- } \\
\text { opment plan. }\end{array}$ & $\begin{array}{l}\text { The plan sets renewable energy } \\
\text { development goals for } 2010 \text { and } \\
2020 \text {. }\end{array}$ \\
\hline 2008 & $\begin{array}{l}\text { National Development } \\
\text { and Reform Commision }\end{array}$ & $\begin{array}{l}11 \text { th five year develop- } \\
\text { ment plan for renewable } \\
\text { energy. }\end{array}$ & $\begin{array}{l}\text { Based on the medium to long } \\
\text { term renewable energy develop- } \\
\text { ment plan, the document sets } \\
\text { renewable energy development } \\
\text { goals ( including modified ones) } \\
\text { for } 2010 \text { and provides for specific } \\
\text { action plans. }\end{array}$ \\
\hline 2009 & $\begin{array}{l}\text { Ministry of finance and } \\
\text { ministry of construc- } \\
\text { tion. }\end{array}$ & $\begin{array}{l}\text { Building PV subsidy } \\
\text { policy }\end{array}$ & $\begin{array}{l}\text { A subsidy of } 2.90 \text { US dollar per } \\
\text { watt (in 2009) is provided for } \\
\text { large scale (50 KW or larger) } \\
\text { PV panels that meet minimum } \\
\text { conditions (energy conversion } \\
\text { efficiency at } 16 \% \text { for monosilicon } \\
\text { PV cells , } 14 \% \text { for polysilicon PV } \\
\text { cells and } 6 \% \text { for non silicon PV } \\
\text { cells. }\end{array}$ \\
\hline 2009 & Ministry of finance & Golden sun pilot project & $\begin{array}{l}\text { The document provides for } \\
\text { subsidies to be given to } 500 \mathrm{MW} \\
\text { or larger PV plant projects in } \\
\text { the coming two or three years. } \\
\text { A subsidy will cover } 50 \% \text { of a } \\
\text { total project investment amount in } \\
\text { principle. The percentage may be } \\
\text { raised to } 70 \% \text { for some unelectri- } \\
\text { fied regions. }\end{array}$ \\
\hline 2009 & $\begin{array}{l}\text { National People's } \\
\text { congress }\end{array}$ & $\begin{array}{l}\text { Revision of the renew- } \\
\text { able energy law. }\end{array}$ & $\begin{array}{l}\text { The revised law was passed on } \\
\text { December 26, } 2009 \text {. }\end{array}$ \\
\hline
\end{tabular}

Fusing East and West

\section{3}

Source: "China energy development report 2009" and KanSichao, Chinese photovoltaic market and industry outlook, IEEJ April 2010 